\title{
Runoff and focused groundwater-recharge response to flooding rains in the arid zone of Australia
}

\author{
R. Ian Acworth ${ }^{1} \cdot$ Gabriel C. Rau $^{1,2} \cdot$ Mark O. Cuthbert $^{1,3} \cdot$ Keith Leggett $^{4} \cdot$ Martin S. Andersen $^{1}$
}

Received: 29 April 2020 / Accepted: 1 December 2020 / Published online: 7 January 2021

(C) The Author(s) 2020

\begin{abstract}
A groundwater recharge investigation in the arid zone of Australia is presented. The investigation used a wide range of hydrogeological techniques including geological mapping, surface and borehole geophysics, groundwater hydraulics, streambed temperature and pressure monitoring, and hydrogeochemical and environmental tracer sampling, and it was complemented by analysis of rainfall intensity from 18 tipping-bucked rain gauges, climate data and stream runoff measurements. Run-off and recharge from a 200-mm rainfall event in January 2015, the largest daily rainfall in the local 50-year record, were investigated in detail. While this major storm provided substantial run-off as a potential source for focused, indirect recharge, it only produced enough actual recharge to the shallow aquifer to temporarily halt a long-term groundwater recession. A series of smaller rainfallrunoff events in 2016 produced a similar recharge response. The results suggest that the total magnitude of a flood event is not the main control on indirect groundwater recharge at this location. A deeper aquifer shows no hydraulic response to surface-water flow events and is isolated from the shallow system, consistent with its Pleistocene groundwater age. This supports a growing body of evidence indicating that attributing or predicting generalised changes in recharge to changes in climate in dryland environments should not be attempted without first unravelling the dynamic processes governing groundwater recharge in the locality of interest. The results should prompt more detailed and long-term field investigation in other arid zone locations to further understand the episodic and nonlinear nature of recharge in such environments.
\end{abstract}

Keywords Groundwater recharge/water budget $\cdot$ Rainfall/runoff $\cdot$ Equipment/field techniques $\cdot$ Geophysical methods $\cdot$ Australia

\section{Introduction}

Groundwater recharge in drylands is thought to occur increasingly by 'focused' means as aridity increases (De Vries and Simmers 2002, Lerner et al. 1990). This may occur as 'indirect' recharge, a subset of focused recharge whereby recharge occurs due to infiltration from streambeds (Healy 2010) such as the

Gabriel C. Rau

gabriel.rau@kit.edu

1 Water Research Laboratory, School of Civil and Environmental Engineering, UNSW Sydney, King Street, Manly Vale 2093, Australia

2 Institute of Applied Geosciences, Karlsruhe Institute of Technology (KIT), Karlsruhe, Germany

3 School of Earth and Ocean Sciences, Cardiff University, Cardiff, UK

4 Fowlers Gap Arid Zone Research Station, UNSW Sydney, Sydney, Fowlers Gap, Australia ephemeral streams that predominantly drain most drylands. However, very few field-based studies which describe and quantify focused recharge processes are available and quantifying relative contributions from diffuse and focused recharge in many dryland settings is an ongoing, and very challenging, research task (Cuthbert et al. 2019a). So, while it is well accepted that indirect recharge is common in arid and semi-arid areas (Lloyd 1986; Lerner et al. 1990; Simmers 1997; Cuthbert et al. 2019b), Shanafield and Cook (2014) recommended long-term data collection to reconcile transmission losses and infiltration estimates with actual aquifer recharge to better understand and quantify groundwater recharge.

However, runoff in the arid zone commonly occurs as a result of extreme rainfall events, often the result of exceptional storms. Under such circumstances, monitoring infrastructure, if present, often fails or is destroyed, often leaving only estimates of runoff occurrence, rainfall distribution and general assumptions concerning groundwater recharge. Such monitoring challenges (Pilgrim et al. 1988) can curtail the development of models from which to estimate runoff and 
groundwater recharge. In the absence of any better model, groundwater recharge has therefore sometimes been estimated as some percentage of average annual rainfall by those responsible for regulating the resource, although this was specifically identified by Gee and Hillel (1988) as a problematical approach. More recently there have been significant steps forward in field-based research to quantify focussed recharge in drylands and a brief review follows.

Using streamflow records in an arid system, Lange (2005) concluded that transmission from less frequent but larger events is more significant compared to more frequent and smaller flows. Blasch et al. (2006) used a two-dimensional (2D) array of temperature and time-domain reflectometry (TDR) sensors buried in the streambed sediments of an ephemeral stream to monitor the space-time evolution of infiltration. They found that the transient higher infiltration during a relatively short period at the beginning of a flow event provided an average of $18 \%$ of the total infiltration recorded during the whole event. Dahan et al. $(2007,2008)$ designed a new approach to monitor the moisture evolution in sediments due to recharge using flexible time-domain reflectometry (FTDR) probes. Their results showed that infiltration is a complicated combination of matrix, preferential and lateral flow. Villeneuve et al. (2015) found that arid zone stream loss and sediment heterogeneity resulted in perched aquifers which persisted for months with slowly declining water levels after flow events. Significantly, they concluded that while most of the perched water feeds evapotranspiration, some leakage occurred that recharged the deeper regional aquifer.

Cuthbert et al. (2016) quantified groundwater recharge beneath ephemeral streams using a novel water-table fluctuation approach which was then applied to several locations in Africa (Cuthbert et al. 2019b). Rau et al. (2017) developed a new methodology that used natural heat measured by vertical arrays of temperature and pressure sensors installed beneath an intermittent streambed. They calculated the apparent thermal diffusivity from data during surface flows and used this to detect the presence and movement of water. Shanafield et al. (2020) reported that simple geophysical measurements relating to streambed hydraulic conductivity could help establish the propensity for recharge. They measured streambed apparent conductivity using hand-held electromagnetic induction equipment and related high apparent electrical conductivity to an assumed high clay content and hence low hydraulic conductivity. A similar approach has been made to establish the hydraulic conductivity of streambeds using an array of floating electrodes (Allen and Merrick 2005).

In this paper, a joint interpretation of a range of different measurements in geophysics, groundwater hydraulics, streambed temperature and pressure monitoring, hydrogeochemical and environmental tracer analysis is presented to elucidate the complexity of the arid zone surface-water groundwater exchange processes that occurred in response to a major flooding event in January 2015. To infer conditions under which groundwater recharge occurs, the single large event in January 2015 was set in the context of the available 50-year daily rainfall record. While Acworth et al. (2016a) reviewed the long-term daily rainfall data set for Fowlers Gap and provided a preliminary description of aspects for this site, here the complete groundwater recharge question was analysed using a multitude of additional measurements and a refined hydrogeological interpretation.

\section{Methods}

\section{Fowlers Gap Arid Zone Research Station (FGAZRS): site description, climate and geology}

The FGAZRS covers $359 \mathrm{~km}^{2}$ and is located approx. $110 \mathrm{~km}$ north-east from Broken Hill at longitude of $142^{\circ} \mathrm{E}$ and latitude of $31^{\circ} \mathrm{S}$ in western New South Wales, Australia. The observations were made at the FGAZRS site where there was a long history of detailed rainfall measurements (Acworth et al. 2016a) and a previous history of investigation where many of the geomorphological, geological and hydrological features had been determined (Beavis and Beavis 1984) and allowed a more detailed interpretation of the new data. The FGAZRS Site is also operated by The University of New South Wales (UNSW) in Sydney (Australia) and is supported with full-time administrative and technical staff. The location and essential features are shown in Fig. 1.

Fowlers Gap Arid Zone Research Station (FGAZRS) has an average rainfall of $239 \mathrm{~mm} /$ year that places it in the arid zone of western New South Wales. Daily rainfall data are available from 1970 (Acworth et al. 2016a) and a summary of the annual rainfall, deviation from the mean, and rainfall years above and below a standard deviation from the mean are given in Fig. 2.

The 2015 event was exceptional but only as a single $36-\mathrm{h}$ event in an otherwise average year (Fig. 2). Years with total rainfall greater than $1 \mathrm{SD}$ above the mean were in 1987, 2010, 2011 and 2016; however, an exceptional total rainfall fell in 1974 when the annual mean $(239 \mathrm{~mm})$ was exceeded by 4 times the standard deviation $(140.9 \mathrm{~mm})$. There were 13 days with more than $20 \mathrm{~mm}$ rainfall in 1974 and 59 other rain days during the year. What was common to both 1974 and 2015 was that the Indian Ocean Dipole (IOD) was negative and there was also a La Niña event in the Pacific. Both factors lead to increased rainfall in south-eastern Australia (BoM 2020). However, it is noted that while both the IOD and the La Niña are thought to increase the potential for winter rain (BoM 2020), the 1974 and 2015 rains both occurred in the Australian summer. It seems that such climatic conditions (IOD and La Niña) also allow for the development of inland troughs as well as the cyclones (McKay 2007) that occur in the summer months. 


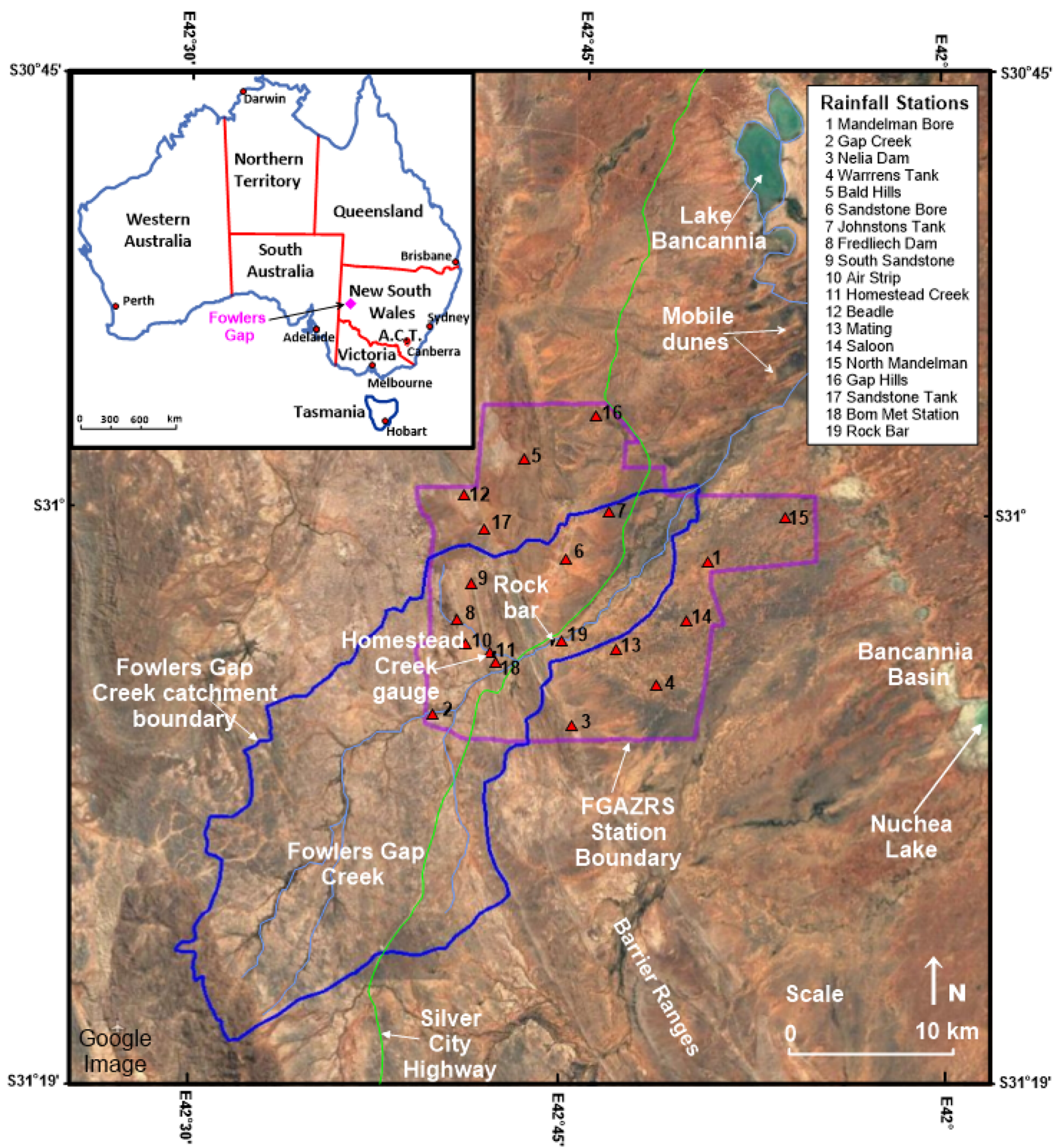

Fig. 1 Location diagram showing the Fowlers Gap Arid Zone Research Station (FGAZRS) boundary in Australia, the Fowlers Gap Creek catchment and the tipping-bucket rainfall stations

Cordery reported (I. Cordery, UNSW Sydney, personal communication, 2016) that during the 1974 wet period, grass grew so high out on the eastern plains at FGAZRS that a Land Rover could get lost. By contrast, towards the end of the Millennium Drought in eastern Australia (Fig. 2), dust storms removed substantial topsoil from a completely bare surface and spread it east as far as Sydney and onto the Pacific Ocean (de Dekker et al. 2014). Since 2016, the area has been in another period of severe drought with 26 rain days in 2019 producing an annual total of only $42 \mathrm{~mm}$.

The FGAZRS straddles the Barrier Ranges (Fig. 1) that are Precambrian in age but have been reduced by weathering to a 


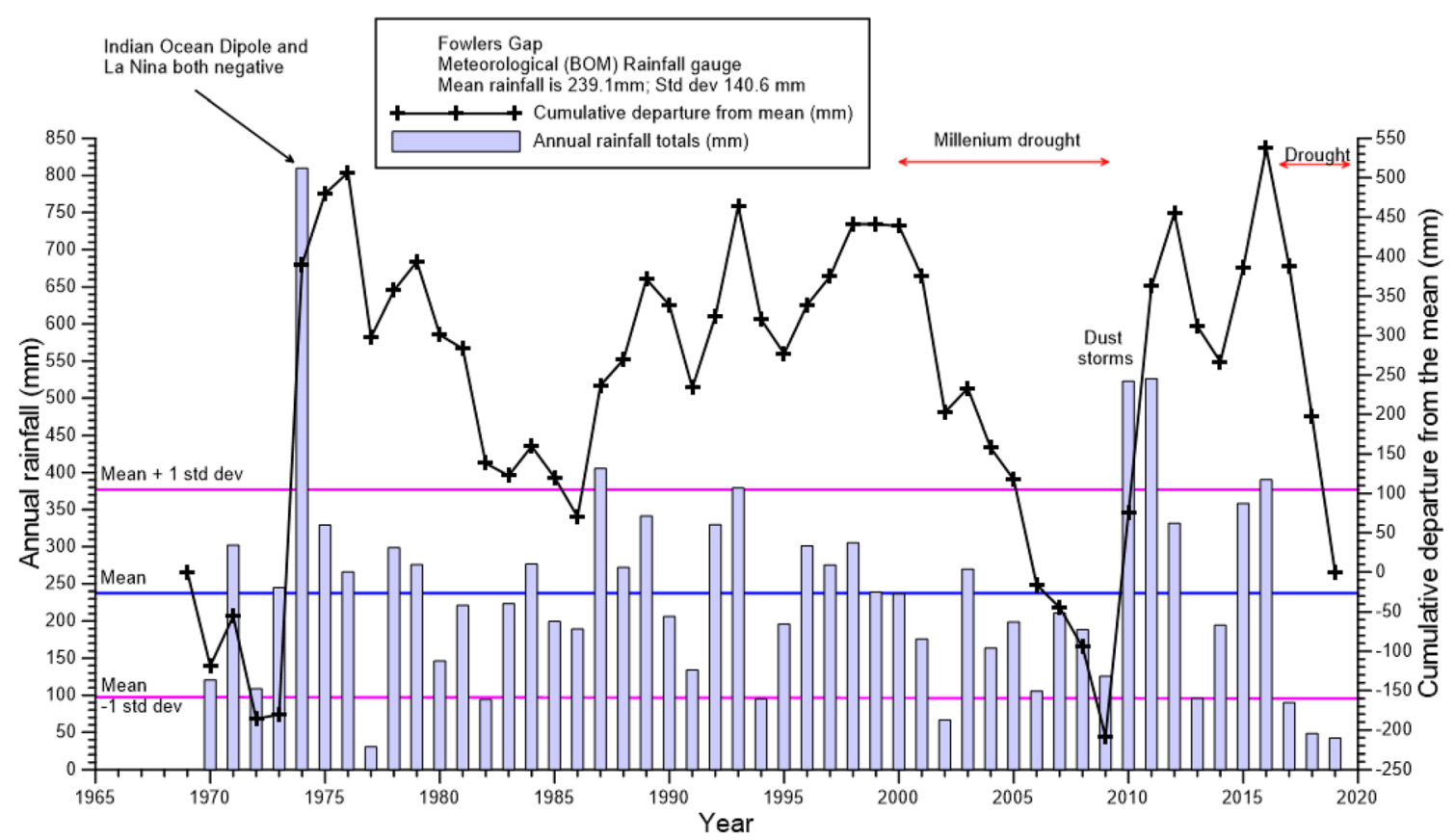

Fig. 2 Annual rainfall data for the Bureau of Meteorology (BoM) climate station (adjacent to station 18 in Fig. 1). The 'cumulative deviation from the mean' allows clear indication of climate variability. The drought commencing in 2016 was the worst in the last 50 years and more significant than the 'Millennium drought'

Runoff was observed to occur after $35 \mathrm{~mm}$ of rain falling on very dry ground and a median value of initial losses of only $15 \mathrm{~mm}$ was established based upon measurements from 46 runoff producing storms measured in 6 runoff plots. These initial results were updated by Cordery (2004) who argued that arid zone surface runoff was a significant and underutilized resource. Unfortunately, the infrastructure installed at FGAZRS as part of the studies by Cordery (2004) was not maintained after the study.

The geology within the FGAZRS boundary is shown in Fig. 3 using a Google Earth satellite image for orientation. Fowlers Gap Creek rises on Precambrian strata that have been strongly folded. Plunging synclines are clearly visible, marked out by residual quartzite ridges formed from the Faraway Downs Quartzite (Beavis and Beavis 1984). These are illustrated schematically in the geology section shown in Fig. 3. Major faulting occurs to the east of the station with downthrow first to the west on the Picnic Creek Fault leaving a thin slice of Willyama metasediments of approximately 1.8 billion years in age outcropping in the Picnic Creek valley. The Willyama sediments are the oldest unit at FGAZRS and form a belt of crushed greenschist with amphibolite dykes and several thin beds of buff coloured limestone.

The Precambrian rocks are low-to-medium-grade metamorphics comprising dolomites, limestones, metaquartzites and phyllites. The metaquartzites resist erosion and form the long linear features clearly seen in the imagery (Fig. 4). The Picnic Creek Fault separates the Precambrian from the Protozoic Willyama Formation. Elsewhere, Lower Devonian 

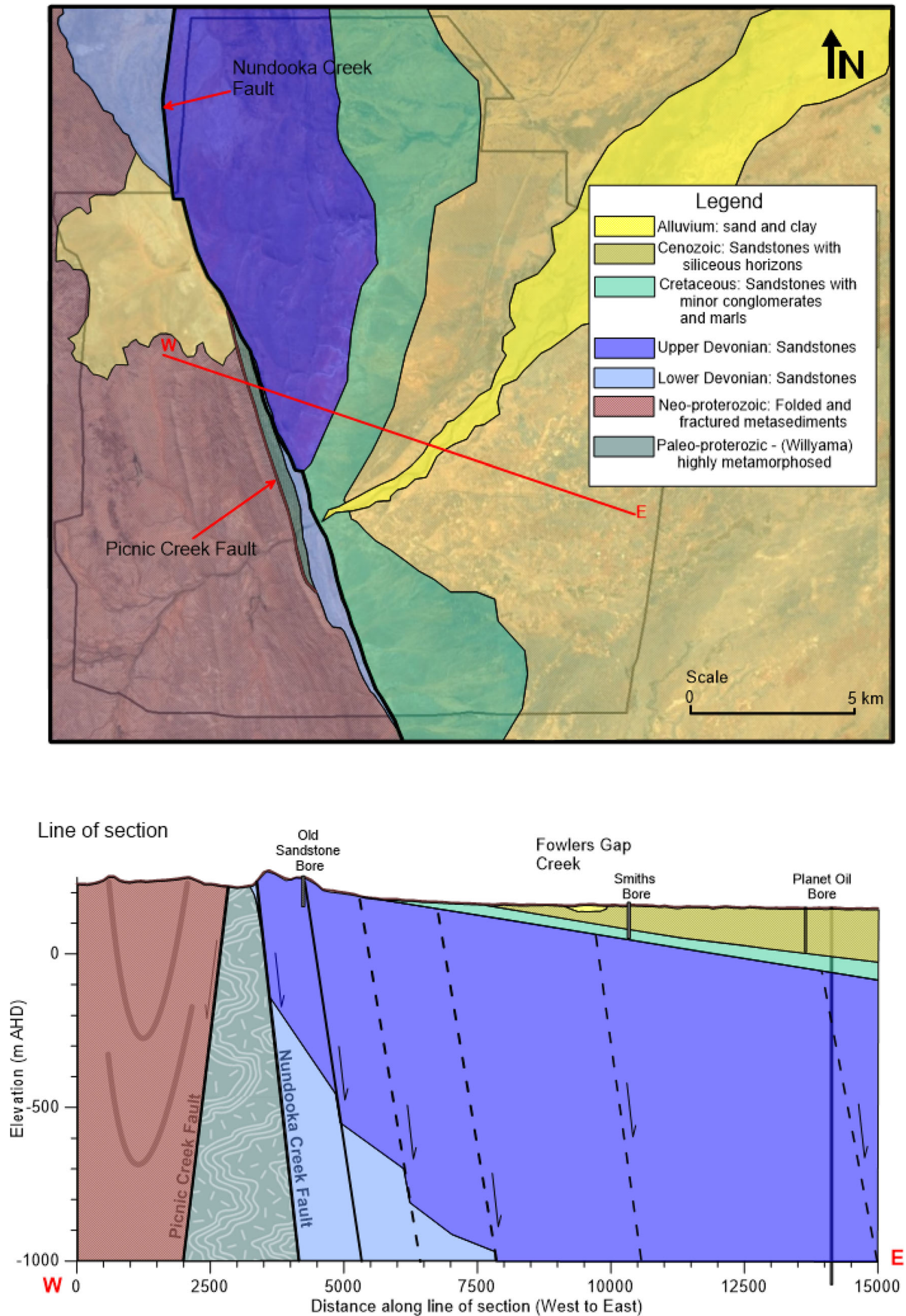

Fig. 3 Sketch map of the geology at the FGAZRS overlain on a satellite image. The geological formations present have been simplified and are based on Beavis and Beavis (1984), Neef et al. (1995) and on new field inspection. A possible 'conjectural flow path' is shown to indicate how water could flow from the recharge area in the sandstone hills out beneath the plains and then to rise up into the Cretaceous and Cenozoic strata 


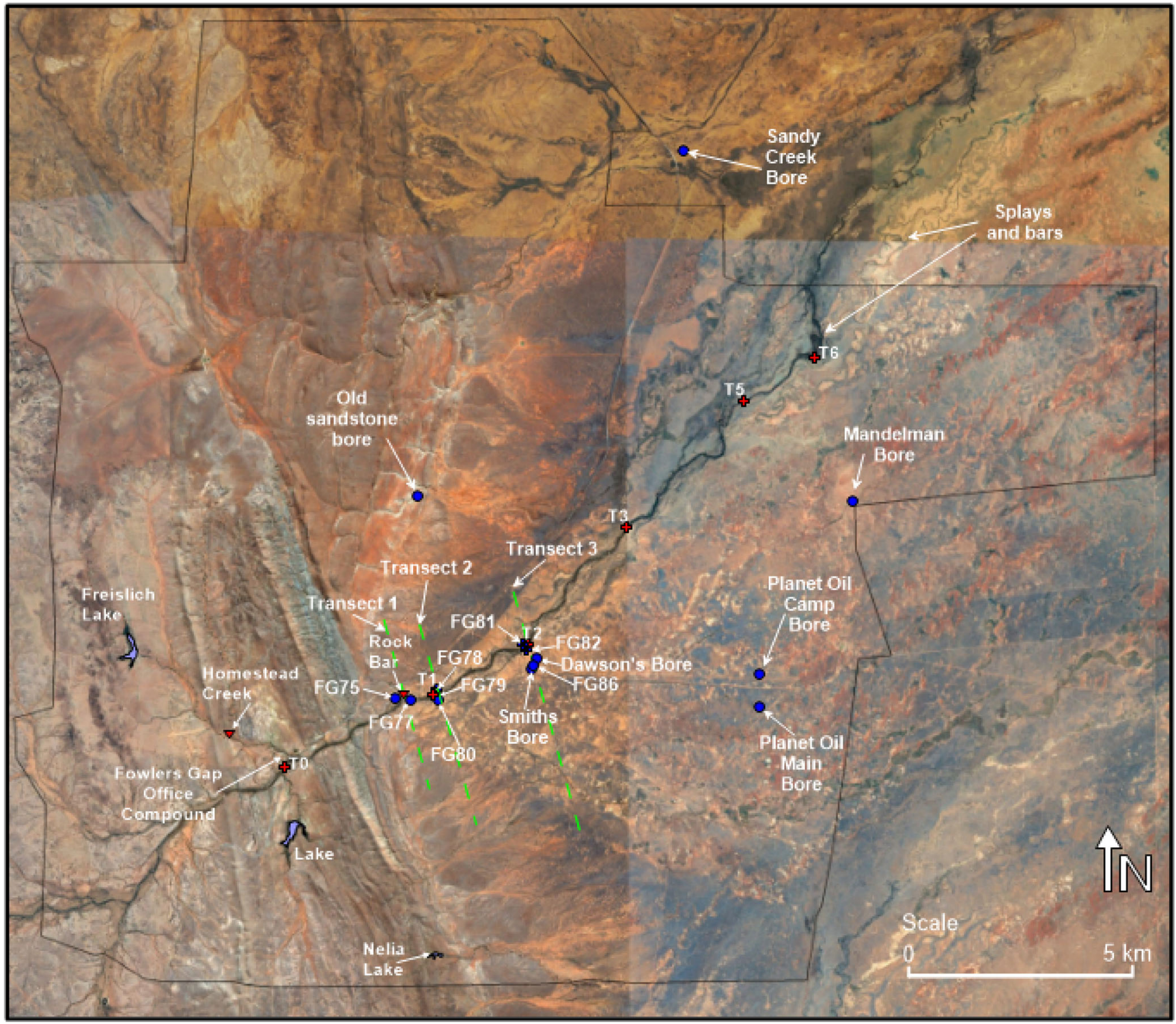

Fig. 4 Location of FGAZRS office compound, lakes, boreholes, gauging stations and streambed temperature arrays (T0-T6). Note that site T4 was abandoned. A higher resolution base map is used to better illustrate the geology shown in Fig. 3. The FGAZRS station boundary is included to provide a reference to Figs. 1 and 3

sandstones are more deformed than the Upper Devonian Nundooka Creek Sandstones.

Drilling for oil in the Bancannia Basin occurred in 1967 and proved volcanic basement of dacite and andesite at 3,257 $\mathrm{m}$ at the Planet Exploration Company's Bancannia South No. 1 well (Planet Oil Main Bore in Fig. 3). Recent and Cenozoic sediments were recorded from the surface to $128 \mathrm{~m}$ with Lower Cretaceous sediments between 128 and $215 \mathrm{~m}$, whereas Devonian sandstone occurs between the base of the Lower Cretaceous and the volcanics at 3,257 m. Particularly porous horizons were recorded in the sandstones between 831 and 1,222 $\mathrm{m}$ and it was noted that they contained freshwater. A thin layer of Cretaceous sands and silts overlie 
the Upper Devonian and were proven in the Planet Oil Main Bore. The age of these deposits is a little uncertain and they may also correlate with the Lower Cenozoic (Palaeocene) Eyre Formation (Neef et al. 1995). The margin between the Cretaceous (or Lower Cenozoic) and Devonian units is difficult to observe on the surface as the younger sandstone sediments have been derived from the older sandstones. Both units comprise brown fine-to-medium sands with crossbedding. An extensive development of silcrete has occurred in the Cenozoic (Oligocene). A massive silcrete occurrence is located crossing the Fowlers Gap Creek at the Rock Bar site (Figs. 1 and 4).

\section{Climate and rainfall measurement}

A climate station (Campbell Scientific) was established on a low hill adjacent to the Rock Bar site with standard parameters (wind speed and direction, rainfall, temperature, humidity, incoming and outgoing radiation as well as barometric pressure). Parameters were recorded at 10-min intervals and transmitted via the mobile phone network to a located at the UNSW Water Research Laboratory (WRL) in Manly Vale, Sydney.

A network of 18 tipping bucket rain gauges was installed at the locations shown in Fig. 1. The date and time of each 0.2-mm tip was recorded on Campbell Scientific CR1000 data loggers and the daily rainfall summed each day at 09:00 and transmitted to the database. Event files that recorded the time of each 0.2-mm tip, or multiples of tips, within a 10-s period were also recorded on the data loggers and subsequently downloaded during later field trips. The loggers were powered by photovoltaic cells with battery backup and transmitted their data using a radio link to one of two transmitter stations established on hill tops within FGAZRS where the data was collected from the individual gauges and sent to the database at UNSW. The equipment was all installed in weatherproof cabinets and the rain gauges protected from animal disturbance by heavy-duty fence and wire enclosures. Wild boars were particularly efficient at disrupting rain gauges that were not well protected.

\section{Groundwater at the FGAZRS}

Beavis and Beavis (1984) report that there are very few groundwater occurrences in the Precambrian rocks to the west of the Nundooka Creek Fault. The research station is supplied with groundwater from boreholes (Smith's and Dawson's) approximately $100 \mathrm{~m}$ deep that terminate in sands at the base of the Cenozoic in the eastern part of the station (Fig. 4).

Groundwater is also pumped from approximately $100 \mathrm{~m}$ depth below ground surface at the Sandstone Borehole site (Fig. 4) in the hills formed from the Upper Devonian Sandstones. The sandstone at this location is well jointed and fractured. It is possible that this horizon continues out onto the plains of the Bancannia Basin and forms the good quality aquifer at depth noted in the Planet Oil Borehole drilling report (Brown et al. 1982). Reliable groundwater supplies are also pumped from similar depths $(90-110 \mathrm{~m})$ at the base of the Cenozoic at the Sandy Creek and Mandelman boreholes (Fig. 4).

Figure 4 provides a higher resolution image base to locate the various installations within FGAZRS and is drawn at the same scale as Fig. 3. A higher resolution satellite image has been used in Fig. 4 to facilitate appreciation of the geological complexity at this site.

The Australian Government invested in groundwater monitoring infrastructure in the National Collaborative Research Infrastructure Strategy (NCRIS) in 2009. A part of these funds was used at the FGAZRS to deploy equipment that could characterise the hydrology of this arid site and provide real-time data in response to hydrological events. The equipment comprised 18 tipping-bucket rain gauges over an area of 36,000 ha, stream gauging of major creek systems, the installation of boreholes to monitor groundwater response, automated climate station monitoring, and the deployment for a limited time period of streambed temperature and pressure arrays in the nearsurface sediments of the Fowlers Gap Creek.

As a part of the NCRIS investment new boreholes were installed in three transects across Fowlers Gap Creek in 2013 (Fig. 4 gives locations). The drilling and completion data are summarised in Table S1 of the electronic supplementary material (ESM). The boreholes were drilled by the then NSW Department of Water Resources using mud-flush drilling techniques. The department gave each of the boreholes a state registration number GW02732xx. For convenience this number has been shortened to FGxx in this paper. At sites FG78, FG81 and FG82 a shallow and a deep piezometer were each installed in separate boreholes.

\section{Stream gauges, streambed and groundwater monitoring}

Bubbler gauges (HS-30 Mark II from Hydrological Services, Australia) were installed at Freislich Dam, Homestead Creek above a concrete weir and at the Rock Bar on Fowlers Gap Creek (Fig. 4). These instruments measured the water levels at 15-min intervals and the data was included in the transmissions to the database at UNSW Sydney. The Homestead Creek and the Rock Bar sites were also recorded using digital cameras and images transmitted daily at 09:00.

Streambed monitoring was carried out at six locations (T0, T1, T2, T3, T5 and T6) shown on Fig. 4. At locations T0, T5 and T6, a single water pressure and temperature logger (SOLINST EDGE, Solinst Canada Ltd., Canada) was installed in a vertically orientated short section of $25-\mathrm{mm}$ PVC pipe located at the sediment surface. The pipe was anchored to large boulders and secured with two star pickets 
concreted in place with a $20-\mathrm{kg}$ bag of quickset cement to protect the pipe from scour during flooding events. At the intermediate locations (T1, T2 and T3), four loggers were installed in approx. 1-m lengths of 25-mm PVC pipe arranged vertically in the streambed and secured in the same manner. The top logger was placed at the sediment surface and the remaining loggers at depths of $0.29,0.42$ and $0.99 \mathrm{~m}$. The top and bottom loggers were Solinst Edge units recording both level and temperature. The intervening sensors were temperature loggers (Hobo Water Temp Pro v2, Onset Computer Corporation, USA). This arrangement thus provided four measurements of temperature at increasing depth and the hydraulic head at the surface and at $1 \mathrm{~m}$ depth beneath the creek bed. The loggers were all initialised and synchronised to record concurrently at intervals of $30 \mathrm{~min}$. The pipes containing the assembled arrays of loggers were hung into a swimming pool overnight to determine the zero head gradient pressure values to compensate for any potential pressure transducer offsets. A separate atmospheric pressure logger (Baro Edge, Solinst Canada Ltd., Canada) was installed in the air-space of Borehole FG81-1 to provide data to remove the atmospheric pressure response from the unvented (absolute gauge) pressure transducers. Detailed descriptions of this type of streambed array and the installation methods used were given by McCallum et al. (2014) and Rau et al. (2017).

The streambed arrays were deployed on 25 October 2014 and recovered on 15 May 2016. Seven sites had been planned (T0-T6) but it proved impossible to install an array immediately downstream of the Rock Bar as the ground conditions were too difficult. The next site (T1) was $330 \mathrm{~m}$ further downstream and adjacent to the second transect of boreholes. After retrieval of the arrays and instruments, the temperature and pressure measurements were downloaded and analysed. Note that the bottom sensor at T3 was lost during recovery of the array at this site when the sands collapsed into the excavation made to recover the pipe. The absolute pressure data was corrected to gauge pressure using the atmospheric pressure from the barometric pressure logger. The vertical reference for each array was the uppermost pressure transducer. The distances were measured from a high-resolution satellite image. Flow events were indicated by the pressure transducer recording values that were significantly above that of the atmospheric pressure. During times when both the top and bottom vertical transducers recorded heads above atmospheric, the vertical hydraulic head gradient (VHG) was calculated using the relative water levels, array length and the corrections established from the swimming pool calibration bath.

The temperature dataset was used to detect the presence of water as well as to describe the flow conditions in the nearsurface sediments over the depth intervals of the arrays (approx. $1 \mathrm{~m}$ ). The interpretation of the temperature datasets closely followed the method developed and explained in detail in Rau et al. (2017), and is briefly summarised here as follows:
1. For each sensor, a timeseries of the amplitudes of the daily temperature fluctuation were extracted by applying the Fast Fourier Transform using a 3-day sliding subsection and by applying a Hanning window to minimise frequency leakage.

2. For the sensor pairs 1 and 2 (interval 1-2) and 2 and 3 (interval 2-3), the amplitude ratios over time were calculated. Note that the amplitude of the daily temperature fluctuations at the bottom (sensor 4 at depth of $1 \mathrm{~m}$ ) could not be used because it was damped beyond meaningful interpretation.

3. A characteristic amplitude ratio for heat conduction through dry sediments was calculated for each sensor pair as an average across a time window (25 October until 14 November 2014) when the streambed sediments were evidently dry, and no rainfall was recorded. This allowed calculation of the dry thermal diffusivity of the sediments using the distance between each pair. The dry thermal diffusivity was used in combination with the thermal properties for water and sediment to estimate a theoretical thermal diffusivity for water saturated conditions. This value was used to infer the equivalent amplitude ratio for the saturated streambed sediments for each sensor pair.

4. The dry and saturated amplitude ratio values were used to delineate the limits within which no unique interpretation of the physical processes within the respective streambed interval can be made using the amplitude ratio (Rau et al. 2017). Values above the threshold for saturated conditions can be interpreted as fully water saturated and with vertical downward flow of water. Values below the dry threshold can be used to delineate vertical upward flow conditions. The range between these threshold values can either be interpreted as variably saturated or saturated with low flow and hence a unique interpretation cannot be made. Note that the theory assumes that the amplitude ratio for a particular flow-rate remains constant over time.

Groundwater levels in all the NCRIS observation boreholes were recorded using In-Situ Level Troll 700H loggers (In-Situ Inc., USA). Loggers on transects 1 and 2 were connected to the data transmission system and data uploaded daily along with the rainfall and climate data. Loggers on transect 3 were independent and downloaded during later site visits. Groundwater depth in the boreholes was established using a dip meter in August 2013, approximately 3 months after completion of the drilling program, for calibration at various times during the deployment of the loggers, and when the loggers were removed in October 2019. Groundwater heads were corrected for barometric influences using the regression deconvolution method described in Rasmussen and Crawford (1997). This approach calculates a best fit of the influence that barometric pressure has on borehole water 
levels using a convolution of pressure measurements weighted by coefficients at discrete time lags. The latter are referred to as instantaneous response which, as cumulative sum, lead to a barometric response function (BRF). BRFs are diagnostic tests of confinement and barometric efficiency (BE) (Rasmussen and Crawford, 1997; Turnadge et al. 2019) which were established for all groundwater locations using the barometric pressure recorded from the climate station.

\section{Geophysical investigations}

GEOVISTA borehole logging equipment (Geovista, United Kingdom) was used in the deeper boreholes to establish profiles of bulk electrical conductivity and gamma-ray activity. Data were recorded at 10-mm intervals. A LUND multicore cable system was used with an electrode spacing of $5 \mathrm{~m}$ to measure an electrical image across Fowlers Gap Creek to establish the depth of sediment beneath the creek. A gradient array was used with the ABEM LS TERAMETER resistivity equipment (Guideline Geo AB, Sweden). The gradient array comprised eight potential electrode pairs for each current electrode pair, rather than the simple Wenner configuration of one potential electrode pair for each current electrode pair (Acworth 2019). This both increased the survey speed, making use of the Terrameter's ability to measure four potential pairs simultaneously and increased the density of the apparent resistivity data thus allowing an improved interpretation. Mud was used to achieve improved electrode contact under the dry conditions. The apparent resistivity field data was inverted using the RES2DINV interpretation package (Loke 2001, 2016). The electrical image was measured across the creek in November 2016. Although this was nearly 2 years after the flood that forms the focus of this paper, it was not anticipated that the bulk conductivity at depth would have changed significantly.

\section{Water chemistry and environmental tracers}

In November 2016, available boreholes were sampled. Three boreholes were dry and the water in a further three boreholes was too deep to sample with the available equipment that could only pump water from depths less than $50 \mathrm{~m}$. The $\mathrm{pH}$, DO, fluid EC temperature and Eh was measured using Hach HQ40d multi-meters and probes in a sealed in-line Waterra flow cell. Sub-samples for major cations and anions were filtered through $0.45-\mu \mathrm{m}$ Waterra fast-flow filters into PET vials. $20 \mathrm{ml}$ aliquots for cations and trace-elements were acidified with $2 \%$ of $5 \mathrm{~N} \mathrm{HNO}_{3}$. Major cations were analysed by ICP-OES on a Perkin-Elmer Optima 7300. Trace elements were analysed by ICP-MS using a Perkin Elmer NexION 300D. Subsamples for anions were stored cold and dark and were analysed by IC for $\mathrm{Cl}$ and $\mathrm{SO}$, while 25 -ml subsamples were analysed for alkalinity in the field by the Gran-titration method using $0.16 \mathrm{~N} \mathrm{H}_{2} \mathrm{SO}_{4}$. Saturation indices for minerals, like calcite, and ionic charge imbalances were calculated using PHREEQC (Parkhurst and Appelo 2003).

Five boreholes yielded enough water that subsamples could be taken for Carbon-14, tritium and $\delta^{13} \mathrm{C}_{\mathrm{DIC}}$ analysis. These samples were analysed by the ANSTO laboratories in Sydney. Carbon-14 was determined using the ANTARES AMS facility at ANSTO following the method of Fink et al. (2004) and reported as both percent modern carbon (pMC) and conventional radiocarbon ages. Tritium samples were analysed by Liquid scintillation spectrometry using a Perkin Elmer Quantulus instrument achieving detection limits of $\sim 0.05$ TU. $\delta^{13} \mathrm{C}$ was analysed using Gas Bench II coupled to continuousflow Delta V Advantage Isotope Ratio Mass Spectrometer (IRMS) following the method by Assayag et al. (2006).

The concentration of tritium in rainfall $\left(\mathrm{A}_{0}\right)$, expressed in tritium units (TU), over Australia is not known in detail for Fowlers Gap (Tadros et al. 2014) and this limits the determination of the groundwater age. For this reason, the concentration in rainfall potentially responsible for recharge has been estimated by solving the tritium decay equation for the potential rainfall source concentration and performing a simple iteration between the postulated rainfall and potential recharge events using the established decay constant and the observed tritium concentration in TU. The tritium decay equation is.

$A_{t}=A_{0} e^{(-\lambda t)}$

where $A_{t}$ is the observed tritium concentration expressed in $\mathrm{TU}, A_{0}$ is the initial tritium concentration expressed in TU, $t$ is the number of years for the decay, and $\lambda$ is the decay con$\operatorname{stant}=\ln (2) / 12.32=0.056262$.

The carbon-14 derived ages were corrected for contributions of dead carbon from carbonate dissolution. Because DIC decreases from the shallow to the deep groundwater, a $\delta^{13} \mathrm{C}$ mixing model is used rather than a mass-balance on DIC or alkalinity for the correction. The $\delta^{13} \mathrm{C}$ mixing model requires estimates of end-member values: $-23 \%$ o for the soil solution, and $0 \%$ for carbonates were applied (Clark and Fritz 1997). The correction equation supplied by Clark and Fritz (1997) was used as follows:

$t=-8,267 \cdot \ln \left(a^{14} \frac{\mathrm{C}}{q \cdot a^{14} \mathrm{C}}\right)$

where 8267 is the decay constant (Clark and Fritz 1997), $a_{t}{ }^{14} \mathrm{C}$ is carbon 14 activity at a given time (in the groundwater sample) expressed in percent modern carbon, and $a_{0}{ }^{14} \mathrm{C}$ is the initial carbon 14 activity (at time of recharge). $q$ is the correction factor given by

$q=\frac{\delta^{13} \mathrm{C}_{\mathrm{DIC}}-\delta^{13} \mathrm{C}_{\text {carbonate }}}{\delta^{13} \mathrm{C}_{\text {soil }}-\delta^{13} \mathrm{C}_{\text {carbonate }}}$ 
where $\delta^{13} \mathrm{C}_{\mathrm{DIC}}$ is the measured ${ }^{13} \mathrm{C}$-DIC in groundwater, $\delta^{13} \mathrm{C}_{\text {soil }}$ is $\delta^{13} \mathrm{C}$ of the soil $\mathrm{CO}_{2}$, and $\delta^{13} \mathrm{C}_{\text {carbonate }}$ is the $\delta^{13} \mathrm{C}$ of the carbonate minerals being dissolved.

\section{Results}

\section{Geophysical characterisation of the subsurface}

Figure 5 shows the geophysical logging data for boreholes FG78 and FG82 with the depth of the piezometers indicated along with the elevation of the standing water levels recorded on installation (Table S1 of the ESM). The layer of high bulk electrical conductivity $(150 \mathrm{mS} / \mathrm{m}$ or resistivity of $6.6 \mathrm{Ohm} \mathrm{m})$ indicates a stiff red clay with higher entrained salt content at an elevation of approx. $105 \mathrm{~m}$ AHD. The identification of the lithology was made by comparing the drillers log for Smith's bore with the geophysical log for the adjacent borehole FG86. The data for FG86 is included as supplementary information (Fig. S1 of the ESM). Water-bearing sand and gravel is indicated by the lower bulk electrical conductivity and lower gamma-ray activity coincident with the location of the piezometer screens. To allow comparison of the lithology across Fowlers Gap Creek, the bulk conductivity log for FG81 is also shown on Fig. 5 as a plot (cyan colour) on the same axis as the data for FG82.

There is a shallow perched aquifer at FG78-1 (on the bank of Fowlers Gap Creek) at 149 m AHD and a deeper aquifer (FG78-2) that may also be perched at $122 \mathrm{~m} \mathrm{AHD.} \mathrm{The} \mathrm{stand-}$ ing water level at both FG78 piezometers occurs within the screens. The saturated zone at FG82 occurs at $85 \mathrm{~m}$ AHD and represents the top of the aquifer that Dawson and Smith's water supply bores are installed into. This deeper aquifer is separated from the shallower perched aquifer by the thick red hard clay shown in Fig. 5.

The results for part (350-650 m) of a 700-m electrical image measured along transect 2 (Fig. 4) and crossing Fowlers Gap Creek are shown in Fig. 6. The shallow depth (approx. $5 \mathrm{~m}$ ) of alluvium in the creek bed (shown in the inset image (Fig. 6b) is apparent; as is the underlying low resistivity bedrock. The alluvium composition appears to be varied (wide range of resistivities) and to extend to greater depths to the left of the image, possibly indicating old palaeochannels of Fowlers Gap Creek. An area of high resistivity thought to represent dryer sandy material is shown to the north of the creek in the vicinity of FG78.

\section{Rainfall and runoff}

In January 2015 during a 36-h period, approximately $200 \mathrm{~mm}$ of rainfall was recorded at the Bald Hills site (station 5 in Fig. 1). The event was captured by 16 of the 18 tipping bucket rain gauges installed under the Federal Government funded
NCRIS, with only 2 gauges failing due to blockage occurring during the storm. This 36 -h rainfall event was not exceeded in the previous 50 years of record. The storm total for the BoM station was $164.4 \mathrm{~mm}$ with the $111.6 \mathrm{~mm}$ for 11th January nearly exceeded all previous daily maxima (rank 2 of 20 events) in the 50-year record of daily rainfall for station 18 (BoM station), but the combination of this fall with the previous day of $52.8 \mathrm{~mm}$ (rank 19 of the same 20 events) makes the 36 -h total exceptional. The rainfall was well distributed with all gauges showing the same basic structure to the event, which is in contrast to the cumulonimbus storm cell type events more often reported in the literature for arid zones (Sharon 1981) and supports the observation by Cordery (2004) that rainfall at Fowlers Gap tends to be less dominated by cumulonimbus storm events than expected. The cumulative rainfall at each of the 18 tipping-bucket gauges is given as in Fig. S2 of the ESM.

There have been 30 events in the past 50 years where consecutive days (48-h period) have recorded rainfall in excess of $50 \mathrm{~mm}$. The event on 10 January $2015(164.4 \mathrm{~mm})$ was the first ranked event in that series, exceeding the second ranked event $(116.1 \mathrm{~mm})$ by $48.3 \mathrm{~mm}$. It is also noted that of these 30 events, 20 occurred in the January to March period, highlighting the importance of summer low pressure troughs in the delivery of maximum rainfall and that four of these events occurred in 1974. The 2-day (48-h) event data are listed in Table S2 of the ESM.

The January 2015 event developed from a low-pressure trough that dipped down towards Southern Australia as shown by the MSLP analyses for Australia between the 6th and 13th of January 2015 (Fig. S3 of the ESM). A deep (998 mbar) low pressure trough originated over Northwest Australia on 6th January and proceeded to link with a cold front passing to the south of Australia on the 8th of January. By the 10th of January a deep zone of low pressure with two embedded centres had developed with the southern centre (999 mbar) moving southeast towards the area north of Fowlers Gap. Examination of the available (since 2000) MSLP maps for other 2-day events show similar characteristics.

Figure 7 shows the structure of the storm event as recorded at the Bald Hills gauge (station 5, Fig. 1) with the three separate phases clearly evident, separated by short periods with no rainfall. The rainfall data is compared with the surface water levels at the Rock Bar on Fowlers Gap Creek, at the gauging station on the tributary Homestead Creek and the level in the dam at Freislicht Reservoir, which is located in the headwaters of Homestead Creek. The Homestead Creek gauge results show a very close match to rainfall that indicates rapid runoff. The runoff also provides a rapid response to the Freislicht Reservoir level. The gauge data for the main channel on Fowlers Gap Creek shows the same basic pattern but the catchment to the south of FGAZRS has a more significant influence during storm phases 1 and 2; with possibly higher 


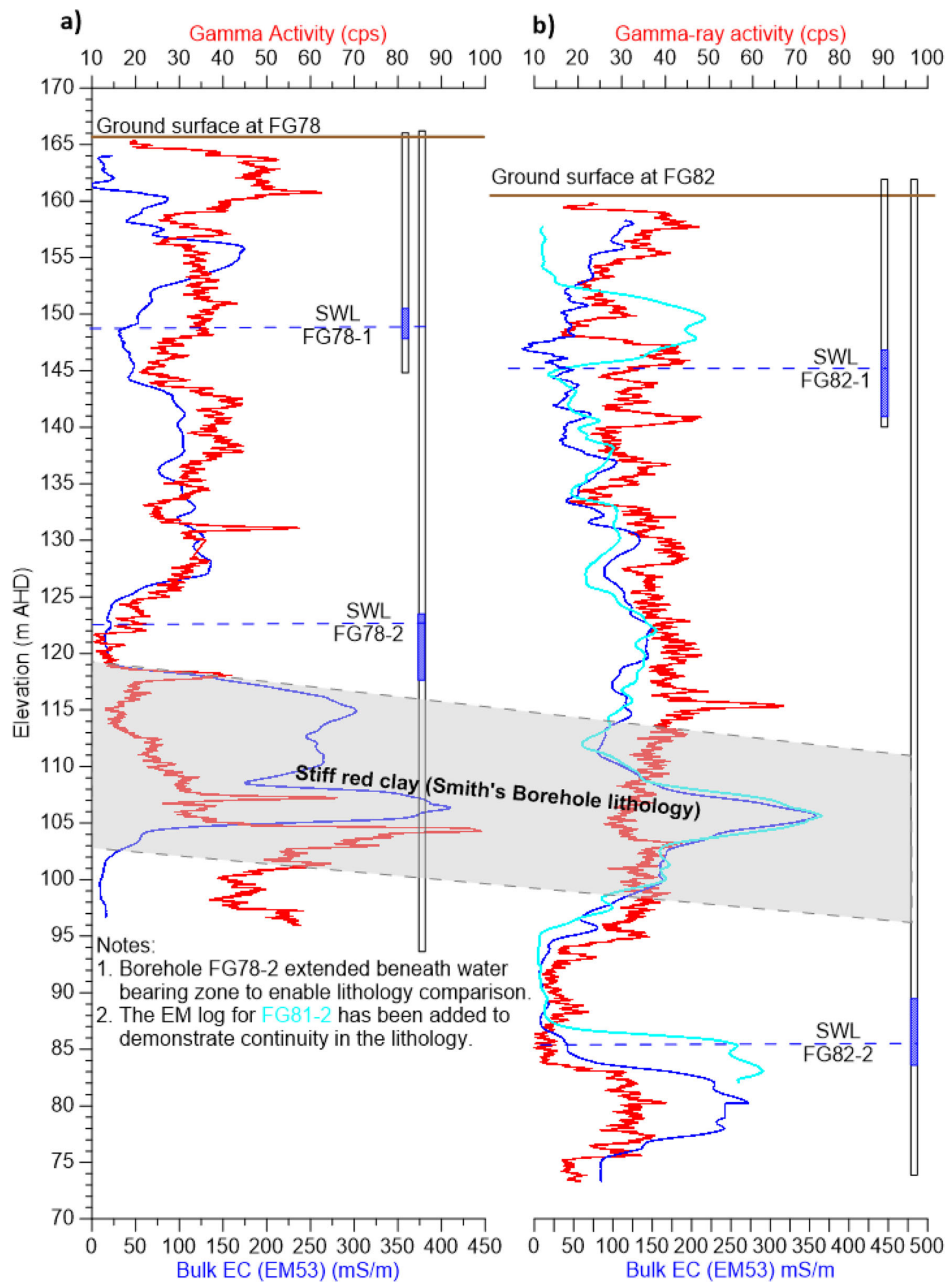

Fig. 5 Geophysical logs for a Borehole FG78 on the north side of Fowlers Gap Creek along transect 2 and b FG82 at the southern side of the creek of transect 3 (Fig. 4). Note that FG78-2 was drilled to greater depth for the collection of geological information and screened to total

drilled depth to enable geophysical logging to be undertaken. A 'higher electrical conductivity layer' is seen in both borehole logs. A bulk conductivity (EM53) log for FG81-2 on the north side of the creek is also shown in cyan 


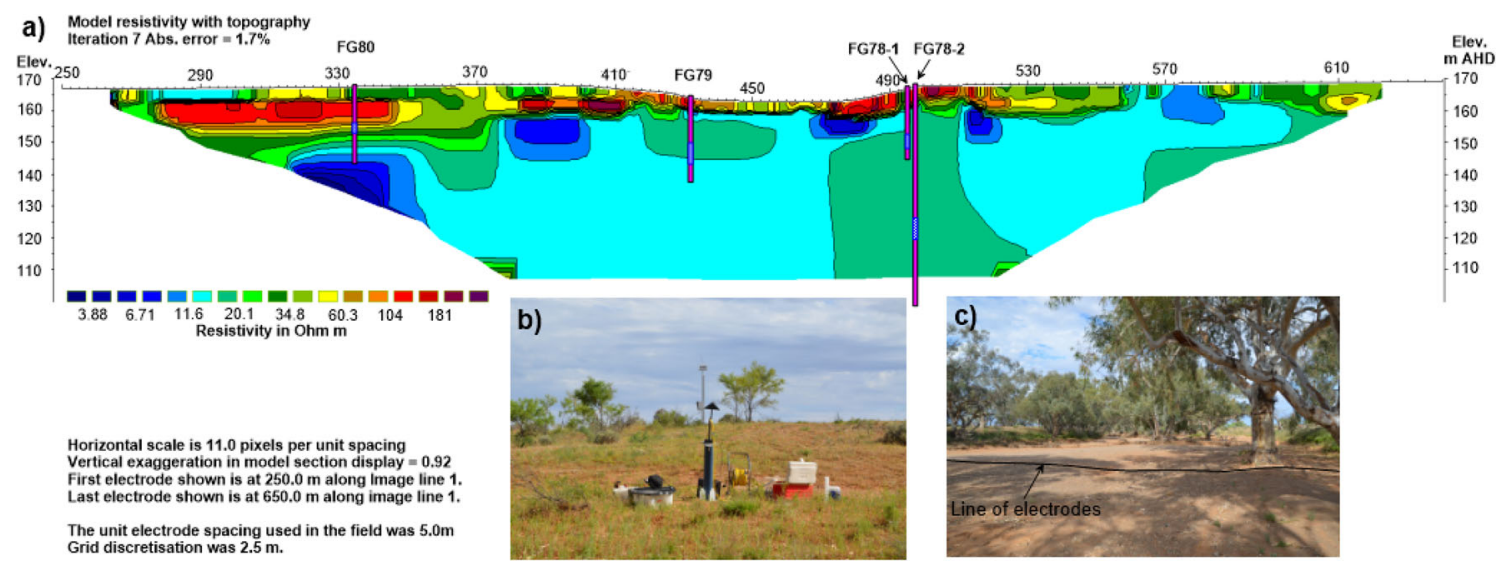

Fig. 6 a Part of the electrical image results along Transect 2. The locations of boreholes with screen depths and the temperature probe $\mathrm{T} 2$ are shown. b Photograph taken looking to the left at FG79 (FG80 is visible at the top of the ridge behind FG79) while chemical sampling was underway in November 2016; c Photograph taken in the creek bed with the 'image cable' shown rainfall recorded in that part of the catchment. The southern part of the catchment is not gauged (Fig. 1) and more rain gauge data in that area would be of use in the determination of catchment rainfall runoff characteristics.

The rainfall intensities have been calculated from the tipping-bucket rain gauge event data over a 38-month time span and are presented for all 18 gauges in Table 1. Station number locations are given in Fig. 1. The maximum 10-s rainfall intensity and the maximum 15-min totals for all gauges for the period 29 August 2013 to 21 October 2016 are presented along with the same data for the January 2015 storm event for comparison. The total rainfall for the January 2015 event is also shown.

The rainfall intensities recorded for the January event are all lower than the maximum rainfall intensities for the 38month period available (Table 1). This is the case both for

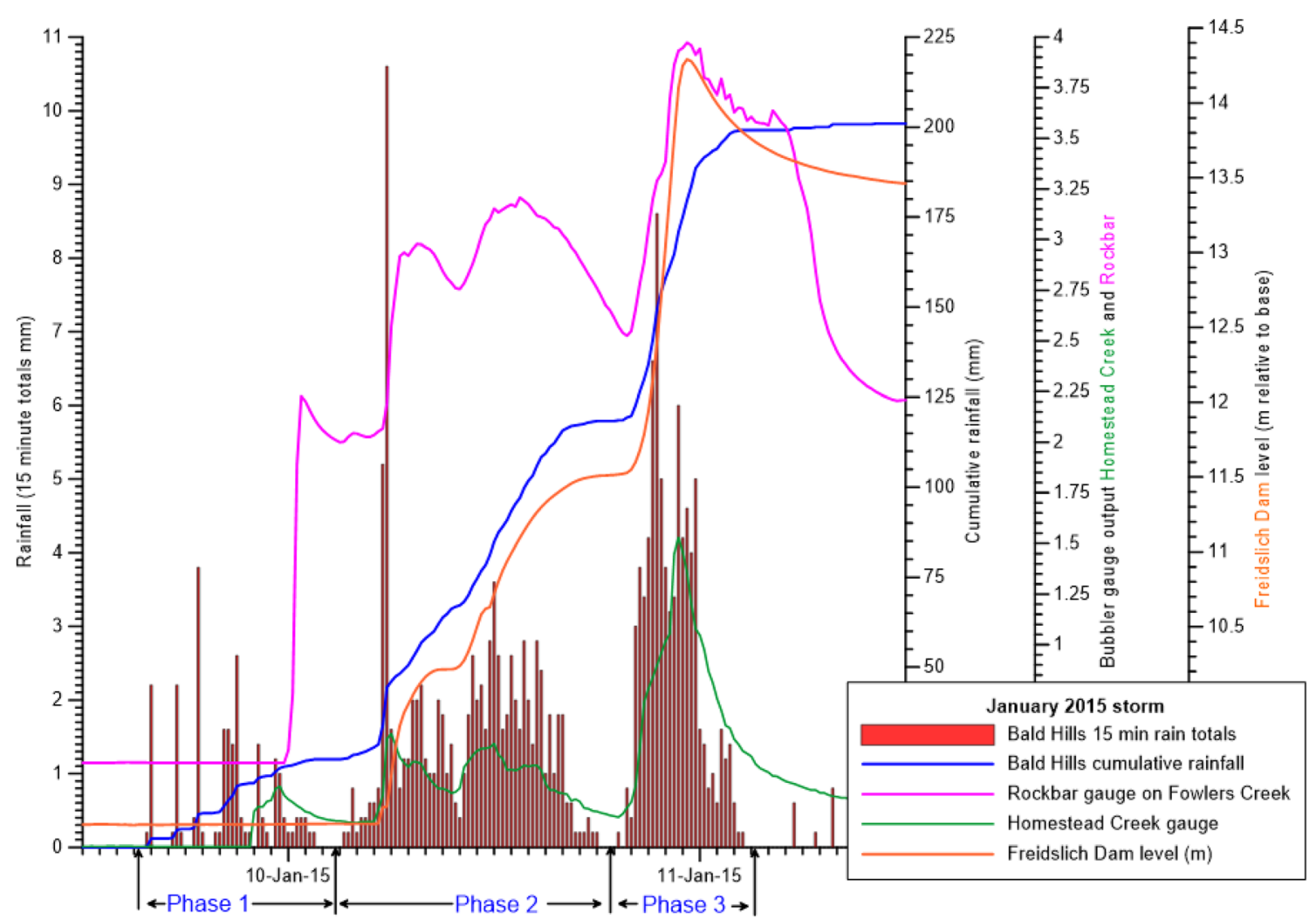

Fig. 7 The hyetograph for the tipping bucket rain gauge at the BoM station showing the three distinct phases of the storm event. The hydrographs for Homestead Creek, The Rock Bar gauging station on Fowlers Creek and the level of water in the Freislicht Dam are provided for comparison 
Table 1 Rainfall intensities at the tipping-bucket rain gauge sites. Stn. No. station number

\begin{tabular}{llllll}
\hline Stn. No. & $10 \mathrm{~s}^{\mathrm{a}}(\mathrm{mm})$ & $15 \mathrm{~min}^{\mathrm{a}}(\mathrm{mm})$ & $10 \mathrm{~s}^{\mathrm{b}}(\mathrm{mm})$ & $15 \mathrm{~min}^{\mathrm{b}}(\mathrm{mm})$ & $\mathrm{Total}^{\mathrm{c}}$ \\
\hline 1 & 0.8 & 19.8 & 0.4 & 7.6 & 168.6 \\
2 & 1.8 & 10.6 & 0.4 & 5.8 & 147.8 \\
3 & 1.6 & 10.2 & 0.4 & 7.4 & 150.0 \\
4 & 4.8 & 28.2 & 0.4 & 9.4 & 162.6 \\
5 & 7.4 & 17.4 & 0.4 & 10.6 & 200.8 \\
6 & 0.4 & 2.6 & 0.2 & 2.6 & 187.2 \\
7 & 1.6 & 25.6 & 0.4 & 7.8 & 193.2 \\
8 & 0.6 & 11.0 & 0.6 & 8.2 & 166.8 \\
9 & 5.4 & 15.4 & 0.4 & 13.2 & 179 \\
10 & 0.6 & 11.4 & 0.4 & 7.8 & 168.8 \\
11 & - & - & - & - & - \\
12 & 1.4 & 10.8 & 0.4 & 10.8 & 175.6 \\
13 & 0.6 & 13.6 & 0.4 & 9.2 & 162.6 \\
14 & 1.6 & 20.2 & 0.2 & 7.2 & 180.5 \\
15 & 0.6 & 18.6 & - & - & - \\
16 & 0.8 & 10.4 & - & - & - \\
17 & 1.2 & 13.2 & 0.4 & 9.6 & 157.2 \\
18 & 1.8 & 15.2 & 0.4 & 178.8 \\
\hline
\end{tabular}

${ }^{\text {a }}$ Maximum 10-s rainfall intensity and the maximum 15-min totals for all gauges for the period 29 August 2013 to 21 October 2016

${ }^{\mathrm{b}}$ Maximum 10-s rainfall intensity and the maximum 15-min totals for all gauges for the January 2015 storm event

${ }^{\mathrm{c}}$ Total rainfall for the January 2015 event the $10 \mathrm{~s}$ and the 15 -min intensities. High intensity rainfall normally occurs from cumulonimbus storm cell activity. The fact that the January 2015 event does not include any of these higher intensity bursts indicates further that there were no storm cells embedded during the January 2015 event. In addition, the January event started at 14:51 on the 9th of January at the western gauge at Sandstone Tank and only reached Saloon Tank $15 \mathrm{~km}$ to the south east (Fig. 1 gives locations) at 17:32 that day. This comparatively slow progression is more likely to be caused by an easterly moving frontal system.

The rainfall intensity data presented here for short bursts of rainfall (10 $\mathrm{s}$ data) at 18 tipping-bucket rainfall gauge sites over an area of $400 \mathrm{~km}^{2}$ is a valuable addition to the characteristics of rainfall in the arid zone. As noted by Dunkerly (2019), such data will be invaluable for developing an understanding of rainfall characteristics representative of changing climate conditions and helps develop better models of rainfall runoff and groundwater recharge mechanisms.

The flood in Fowler's Gap Creek continued to the north outside FGAZRS occupying the various spills and splays visible on Fig. 4 until the flood discharged into Lake Bancannia. The final path taken by the flood is not recorded but will have been influenced by the mobile dunes visible to the south of Lake Bancannia in Fig. 1. After this flood event, the endorheic lake is reported (G. Dowling, UNSW Sydney, personal Communication, 2018) to have held water for the next few years before completely drying up again; however, exact details or times were not monitored.

\section{Groundwater responses}

The hydraulic head variations measured during the 3 years of detailed monitoring (2014-2017) are shown in Fig. S4 of the ESM. The time axis in Fig. S4 of the ESM is extended to show the dip measurements in August 2013 and October 2019 (Table S1 of the ESM) to indicate the longer-term trends in hydraulic head and to provide confirmation that the loggers had not drifted significantly during the deployment. Detailed description of the hydraulic head variations, where the impact of barometric pressure is removed, are presented in the following.

\section{Hydraulic head trends from 2015 to 2017}

The deep boreholes with hydraulic heads at approximately $85 \mathrm{~m}$ AHD (FG86, FG82-2 and FG81-2) show very little change between 2015 and 2017 (Fig. 8). FG86 show repeated 0.05-m responses to pumping from the Smith's Borehole that is $22 \mathrm{~m}$ distant (downward spikes at the time scale used in Fig. 8). There are similar downward spikes in the record of FG82-2 that is presumed to reflect abstraction from Dawson's Borehole. The FGAZRS staff have tended to use the Dawson's Borehole, that was established in 2016, in 


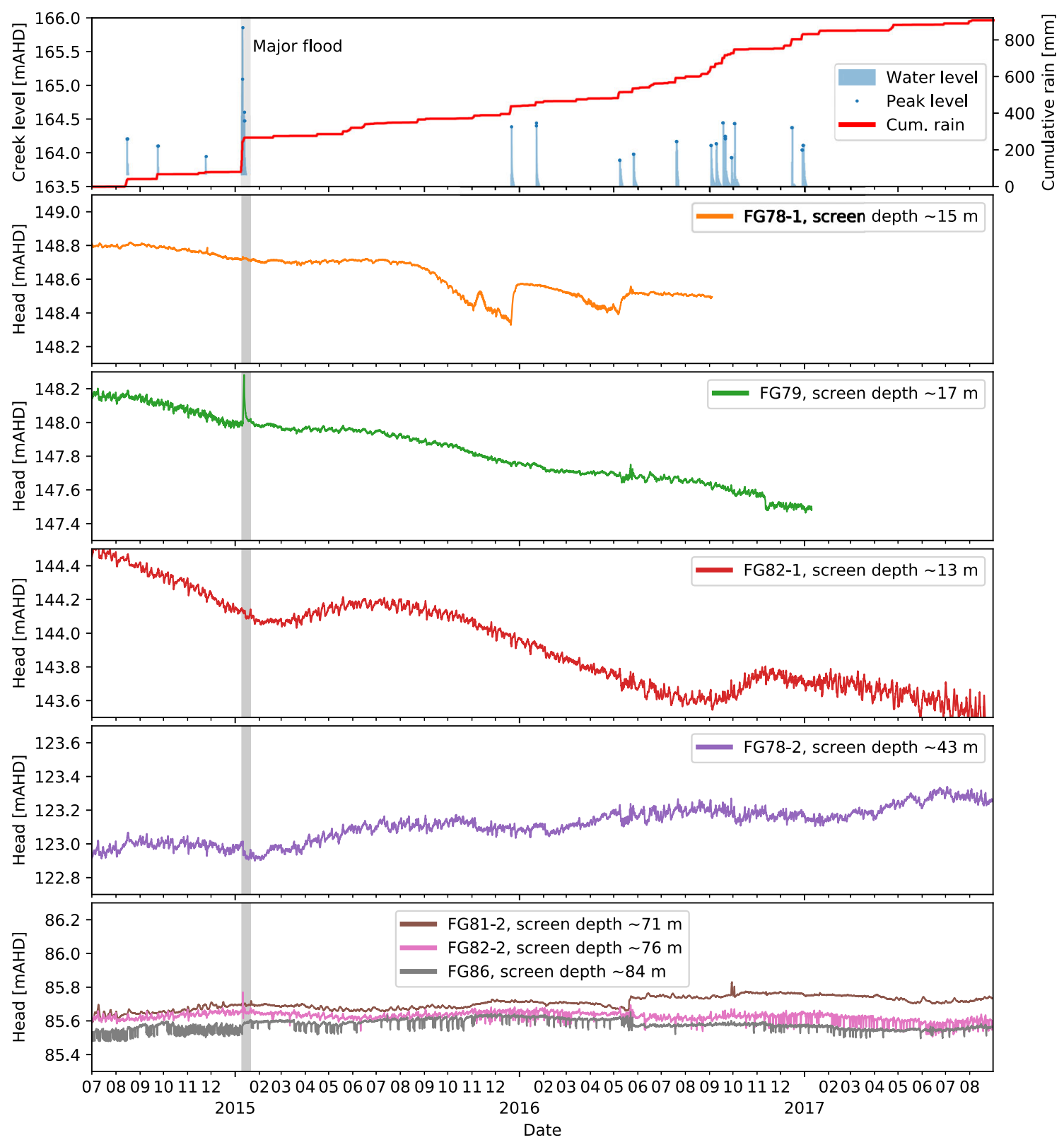

Fig. 8 Hydraulic heads in the NCRIS boreholes at FGAZRS established by hourly monitoring using HERMIT 700H vented transducers (In-Situ Inc). The data have been processed using the regression deconvolution method. Unprocessed hydraulic heads are presented in Fig. S4 of the ESM

preference to Smith's Borehole. FG82-2 is approx. $250 \mathrm{~m}$ distant from Dawson's Borehole. The data set is a useful example of the power of the regression deconvolution method to reveal these small responses. FG81-2 has a hydraulic head similar to that of FG86 and FG82-2 and is also in a similar geological succession (Fig. 5) yet does not show the same response. This is explained by the construction of FG81-2 (Table S1 of the ESM) that shows that the final water level is just above the base of the screen, thus complicating the hydraulic response at that borehole.

FG78-2 shows a slowly rising hydraulic head at approx. $123 \mathrm{~m}$ AHD. FG78-2 is completed in a horizon above the stiff red clay that separates the deeper water at $85 \mathrm{~m}$ AHD from the shallower water with a hydraulic head of $144 \mathrm{~m}$ AHD (Fig. 5). The boreholes installed into the upper part of the alluvial sequence (FG78-1, FG82-1 and FG79), with a hydraulic head between 144 and $148 \mathrm{~m}$ AHD, demonstrated that a slow decline in hydraulic head (Fig. 8 and Fig. S4 of the ESM) had occurred over the monitoring period. This slow decline was interrupted by increments of recharge. It was noted that no water strikes were reported during drilling through the $60 \mathrm{~m}$ between the lower zone represented by FG86, FG82-2 and FG81-2 and the upper zone represented by FG78-1, FG82-1 and FG79 with the exception of a small quantity of water at FG78-2. 


\section{Responses to the January 2015 flood event}

Borehole FG75 was sited upstream of the rock bar on transect 1 and proved solid rock at $9 \mathrm{~m}$ depth which was thought to be the same silcrete that forms the rock bar. The logging data showed no response until the water level in the flood enters the borehole by overtopping at the height of the third phase of rainfall and the maximum level recorded by the adjacent bubbler gauge. Investigations have shown that the sensor in FG75 was damaged during the flood event and stopped working shortly afterwards. However, a similar behaviour is seen in borehole FG77 installed downstream of the rock bar. This borehole was also drilled to solid rock at $5.5 \mathrm{~m}$ with overlying clays, sands and gravels. Both boreholes were dry before the flood.

Borehole FG77 received water by overtopping at the height of the flood during the third phase of rain (Fig. 9). The top of the piezometer was submerged for approximately $2 \mathrm{~h}$ with a maximum overtopping height of $0.6 \mathrm{~m}$. Evidence of the overtopping is clearly seen in the upper image in Fig. 9 that shows the pile of flotsam from the flood on top of the borehole. The second image in Fig. 9 shows the top of the flood as recorded by the scum line inside the sensor box. During this time, it is inferred that enough water entered the aquifer, by flowing down the inside of the piezometer pipe, that a saturated (perched) zone was created beneath the sediments of the creek bed. This perched zone responded to rainfall on the 13th of January 2015 with a groundwater level rise. The level in Borehole FG77 gradually decreased for 11 days after the flood until a sudden change occurs and the rate of groundwater level then decreased more rapidly with the borehole finally drying up after approx. 24 days. This transition to a steeper groundwater recession occurs at approximately the same time as flow in the creek bed stops (Fig. 9) as a result of the water level above the rock bar falling below the cease-to-flow elevation over the rock bar (noted in Fig. 9). The creek bed then becomes dry in the downstream section (evidenced by sensor at T1).

FG80 on transect 2 was dry when drilled and never recorded any water. FG80 was located at the top of the bank on the south side of the creek and approx. $100 \mathrm{~m}$ distant from the creek (Fig. 5) and was originally intended to monitor water in the alluvial deposits assumed to be present. The screens were set in FG80 at the only sandy material encountered but the elevation of this screened section proved to be above the elevation of water in FG79 and FG78-1 (Table S1 of the ESM).
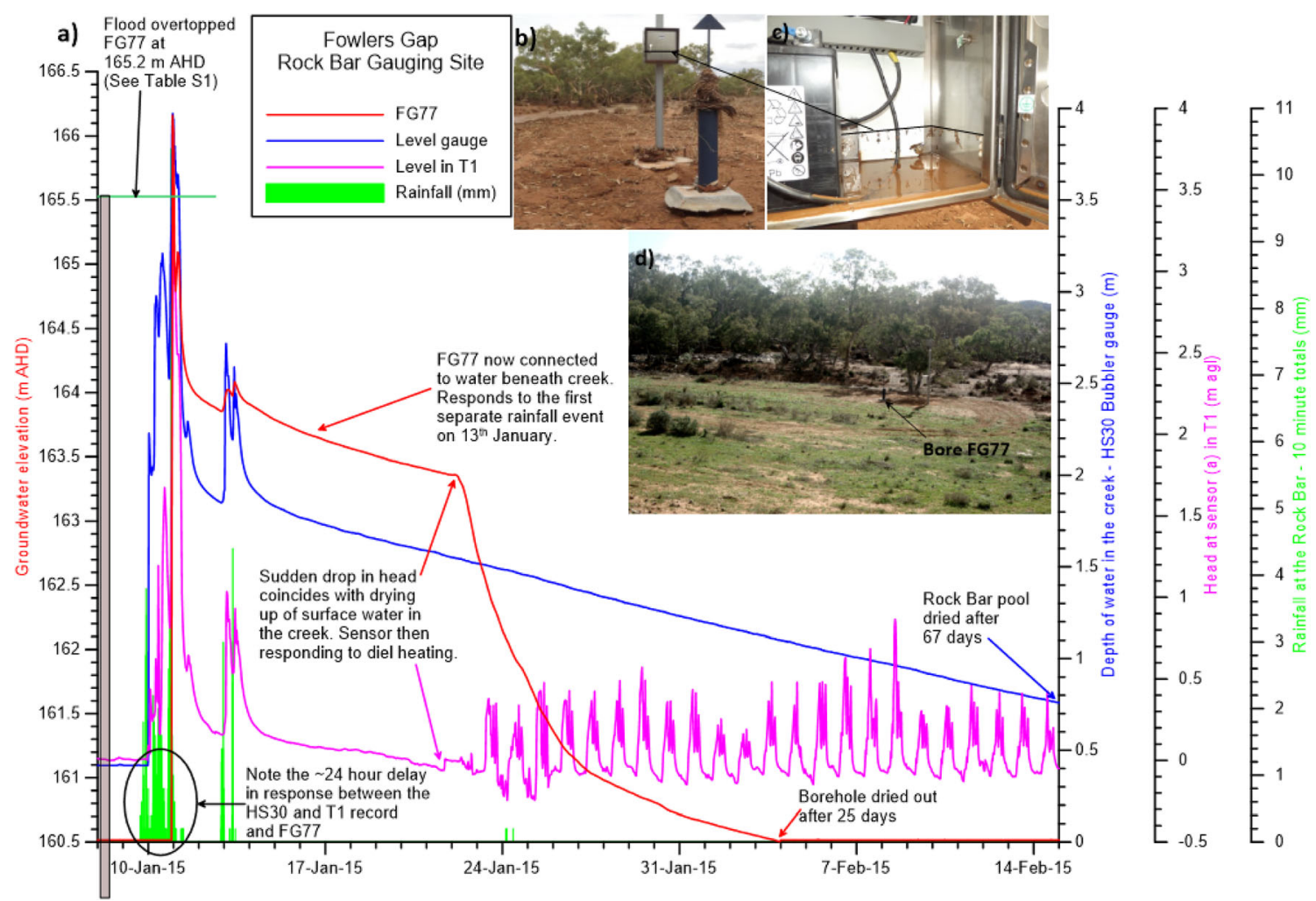

Fig. 9 a Graph showing: hydraulic head response at borehole FG77 downstream from the Rock Bar (red line), the level in the Rock Bar pool recorded using the HS30 bubbler gauge (blue line), the 10-min rainfall totals from the climate station at the Rock Bar site (green bar chart) and; the head of water in the top sensor of the temperature sonde at site T1 (magenta line). Note that Site T1 is $330 \mathrm{~m}$ downstream of the
Rock Bar. b Photograph of the flood debris left on top of the bore (photographer: Gary Dowling). c Evidence of the final flood height from the inside of the instrument box. d General view of FG77 site showing the bore location at the edge of the present flood channel - before the flood. The rocks forming the hydraulic control (rock bar) can be seen on the left under the trees 
Groundwater was encountered at two depths in FG78 (Fig. 5) on the north side of the creek (17.0 and $43.0 \mathrm{~m}$ ) and also at $16.7 \mathrm{~m}$ in FG79 on the south side of the creek. Groundwater shows a confined response at both the shallow and deep boreholes in FG78 and in FG79 when compared to atmospheric pressure (Rasmussen and Crawford 1997).

Similar to FG77 on transect 1, there was no response in FG79 to the flood before the sudden change that occurs at the height of the third phase of rainfall just before midnight on 10th January. The transducer was then out of range for approximately $4 \mathrm{~h}$ during the peak of the flood before decaying back to preflood levels over the next 3 days. However, there is also an apparently delayed response to the flood seen by a flattening of the hydraulic heads over the next 6 months before the heads steepen once more onto the background recession rate. The water level in FG78-1, although at the same depth as FG79, did not respond to the flood at all. The elevation of the water surface in FG78-1 is approx. $0.5 \mathrm{~m}$ higher than FG79 (Fig. 8 and Fig. S4 of the ESM) indicating the possibility of lateral flow beneath the creek, the result perhaps of preferential recharge through the sandy sediments identified close to FG78-1 (Fig. 6).

All three deep piezometers (FG86, FG81-2 and FG82-2) on transect 3 showed no response to the flood. The shallow piezometer at FG81-1 on the north side of the creek was overtopped by the flood but the flood remained below both FG81-2 and FG82-1 piezometer tubes. The shallow piezometer on the north side (FG81-1) became silted up as several metres of silt/sand were washed in during the flood causing the logger to fail shortly after the flood. The logger had also developed a fault prior to the flood. The shallow piezometer on the southern side (FG82-1) shows a delayed response to the flood, with an interruption of the longer-term head recession observed around 60 days later followed by a slight increase in heads and a subsequent decay back to the background recession rate by approximately 11 months later. A SOLINST Baro logger installed at the top of FG81-1 responded to the flood as water entered the borehole.

\section{Stream flow and streambed infiltration}

The streambed arrays track the propagation and evolution of the flood wave as it makes its way from the FGAZRS entrance, through the rock bar and over the sediments of the floodplain along a 17.25-km path (approx. Distance between $\mathrm{T} 0$ and $\mathrm{T} 6$ ). All but the last streambed array shows a complex flood response with multiple peaks as the rainfall continues followed by a slow recession of flow.

The initial rise in head recorded by the uppermost pressure logger in the temperature array indicates the arrival of the flood (Fig. 10). The height of the flood varies as a function of the quantity of water running in the creek and the crosssectional area of the creek at the sensor site. The highest recorded surface-water level was $4.50 \mathrm{~m}$ above the streambed surface at T3. Note that the flood spilled out of the main channel during the runoff from the 3rd phase of the storm (Fig. 7). The average velocity of the flood front propagation over the entire $17.25 \mathrm{~km}$ between T0 and T6 was $1.64 \mathrm{~km} / \mathrm{h}$ (Table 2) although the velocity of the flood front increased over the span of the event as the contribution of runoff increased. Note also that the response to the third phase of rainfall that began at approximately 20:00 on the 10th of January was much more immediate as a result of the catchment being saturated and the channel already partially full of water.

Table 2 shows the arrival times of the flood at each of the temperature sensor sites. Note that water levels were only measured every $30 \mathrm{~min}$, limiting the accuracy of peak detection and therefore also horizontal velocity determination. The beginning of the storm is indicated by the rapid fall in temperature as rain wets the sediments in the creek bed. This occurs well before the arrival of the flood front. Note that the flood front velocity increases as it moves downstream and that at $\mathrm{T} 0$ and $\mathrm{T} 1$ there is a significant lag between the first water arriving and the principal flood front. At downstream locations, the flood front is not preceded by any runoff water.

Figure 10a shows the water levels as measured by the surface sensor at each of the 6 sites, as well as the 15-min rainfall recorded at the Bald Hills station for the 3-day period in January 2015. The top sensor record for site $\mathrm{T} 1$ indicates that the creek carried water for 13 days after the initial flood spate. The bottom sensor at $1 \mathrm{~m}$ depth indicates that the sediments remained saturated at that depth until the 28th of February 2015, approx. 49 days later.

The vertical head gradients (VHG) in Fig. 10b demonstrate a strong downward gradient of approx. -1 right at the beginning of the flood in January 2015. The gradient reaches its maximum at the beginning of the second surface-water level peak within this flood event before rapidly decreasing to below the initial value. While the third surface water level peak does not seem to influence the VHG by much, the fourth peak increases the VHG again. This is followed by a reversal of the VHG in the upward direction as the last peak recedes. Although smaller than the downward VHG, the upward gradient slowly decreases towards zero before the water level disappears below the surface (Fig. 10).

Figure 11 presents an overview of the diel temperature amplitude ratios recorded between the sensor intervals $1-2$ (surface to $290 \mathrm{~mm}$ ) and 2-3 (290-420 $\mathrm{mm}$ ) alongside the water levels and precipitation (scaled logarithmically) for the time period between 15 November 2014 to 1 March 2015 . The dry and saturated limits to the amplitude ratios were used to individually scale the colours plotted. This allows a normalised comparison between the data sets for the different sites to be established. The colour bar was designed to allow a quick assessment of either downward or upward flow conditions when the streambed is water saturated, as indicated by the 


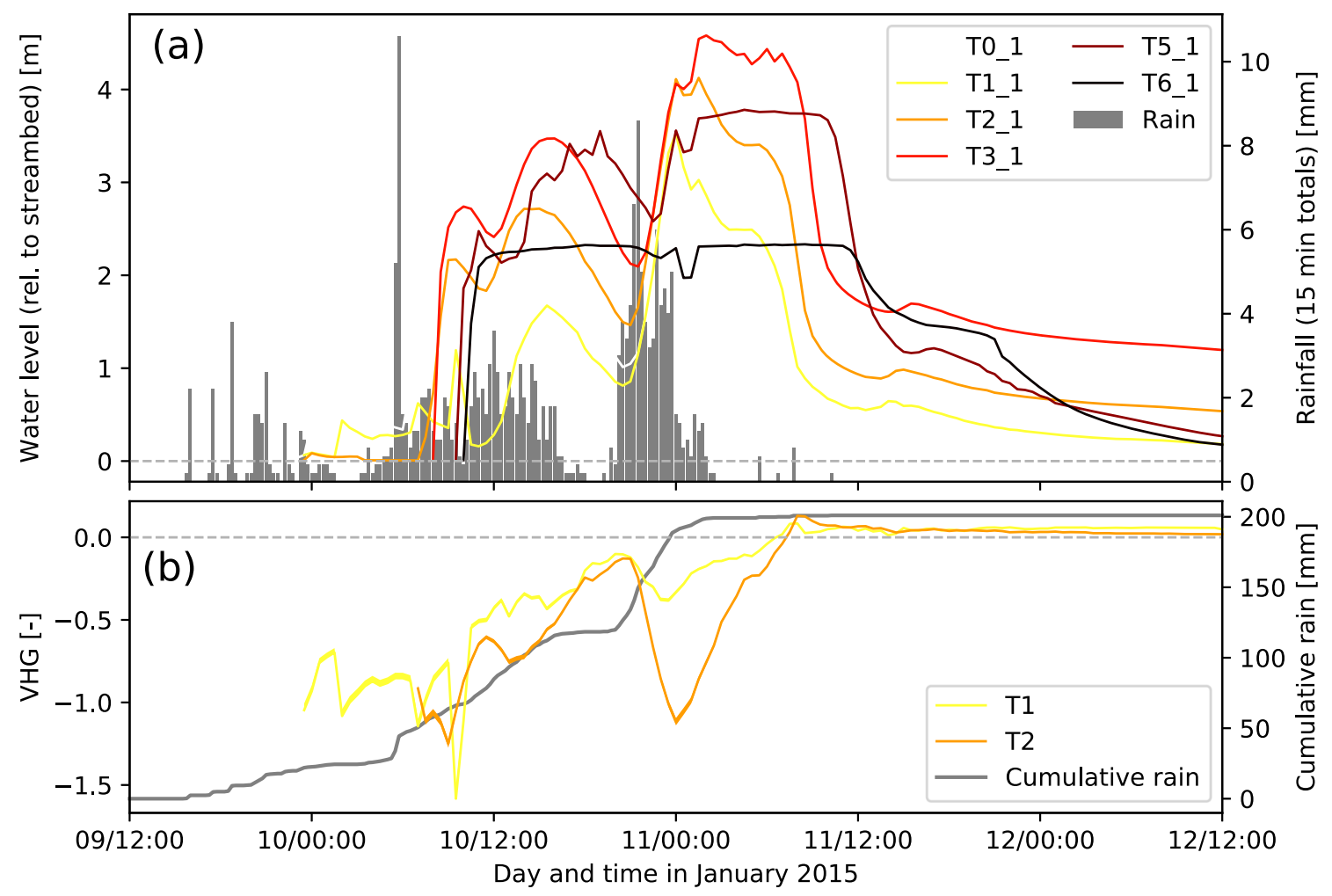

Fig. 10 a Water levels above the streambed (indicated by the grey dashed line) measured by the surface sensor at each of the streambed array sites. The distances down the creek from the uppermost upstream sensor (T0) at the FGAZRS entrance and the downstream sensors are 3,460 $\mathrm{m}$ from T0

existence of a water level (black lines). Changes in $A_{\mathrm{r}}$ during periods with no surface runoff, as indicated by a lack of pressure response and unsaturated conditions, should not be interpreted.

The dark red colour (Fig. 11) represents an amplitude ratio $A_{\mathrm{r}}>1$ indicating fully saturated conditions with nonvertical flow through the creek bed sediments. This could be caused by horizontal flow on lower permeability layers or hyporheic flow when conditions are fully saturated. Such flows would violate the conditions of vertical flow required by the analytical model (Rau et al. 2017). Nonvertical flow occurs first between the sensors at T3 $2-3$ in response to a small $(6-10 \mathrm{~mm})$ rainfall event on the 25th of November 2014 and is followed by a short to $\mathrm{T} 1,6,334 \mathrm{~m}$ from $\mathrm{T} 0$ to $\mathrm{T} 2,10,049 \mathrm{~m}$ from $\mathrm{T} 0$ to $\mathrm{T} 3,14,926 \mathrm{~m}$ from $\mathrm{T} 0$ to T5 and $17,256 \mathrm{~m}$ from T0 to T6. Negative values of VHG imply downward flow. $\mathbf{b}$ Vertical head gradients calculated for streambed arrays $\mathrm{T} 1, \mathrm{~T} 2$ and $\mathrm{T} 3$ as well as the cumulative rainfall for comparison

period of downward flow indicated by the less intense red colour $\left(0.7<A_{\mathrm{r}}<1.0\right)$. This quantity of rainfall was insufficient to generate runoff but infiltration and ponding above the sensor at $490 \mathrm{~mm}$ is indicated by the rise in pressure at the bottom head sensor at $1-\mathrm{m}$ depth. The event was recorded at $\mathrm{T} 1$ and $\mathrm{T} 2$ but not at $\mathrm{T} 3$ indicating that the rainfall was from a cumulonimbus storm cell and poorly distributed.

The response to the major flood in January, 2015 is more complex and an interpretation of the 6 panels in Fig. 11 can be summarised as:

- T1_1-2: Rapid onset of fully saturated conditions and downward flow immediately followed by nonvertical
Table 2 Flood arrival time, distances and velocities

\begin{tabular}{llllll}
\hline Sensor site & $\begin{array}{l}\text { Distance from } \\
\text { T0 }(\mathrm{km})\end{array}$ & $\begin{array}{l}\text { Soil wet } \\
\text { (9 Jan) }\end{array}$ & $\begin{array}{l}\text { Arrival time of first } \\
\text { water on 10 Jan 2015 }\end{array}$ & $\begin{array}{l}\text { Arrival time of } \\
\text { flood front }\end{array}$ & $\begin{array}{l}\text { Velocity between } \\
\text { sensors }(\mathrm{km} / \mathrm{h})\end{array}$ \\
\hline T0 & 0 & $17: 30$ & $00: 00$ & $06: 30$ & - \\
T1 & 3.460 & $18: 30$ & $02: 00$ & $13: 00$ & 0.53 \\
T2 & 6.334 & $23: 00$ & $07: 30$ & $07: 30$ & 0.52 \\
T3 & 10.049 & $23: 30$ & $08: 30$ & $08: 30$ & 3.72 \\
T5 & 14.926 & $17: 30$ & $10: 00$ & $10: 00$ & 3.25 \\
T6 & 17.256 & $18: 00$ & $10: 30$ & $10: 30$ & 4.66 \\
\hline
\end{tabular}


Amplitude ratio $A_{r}(t)[-]$
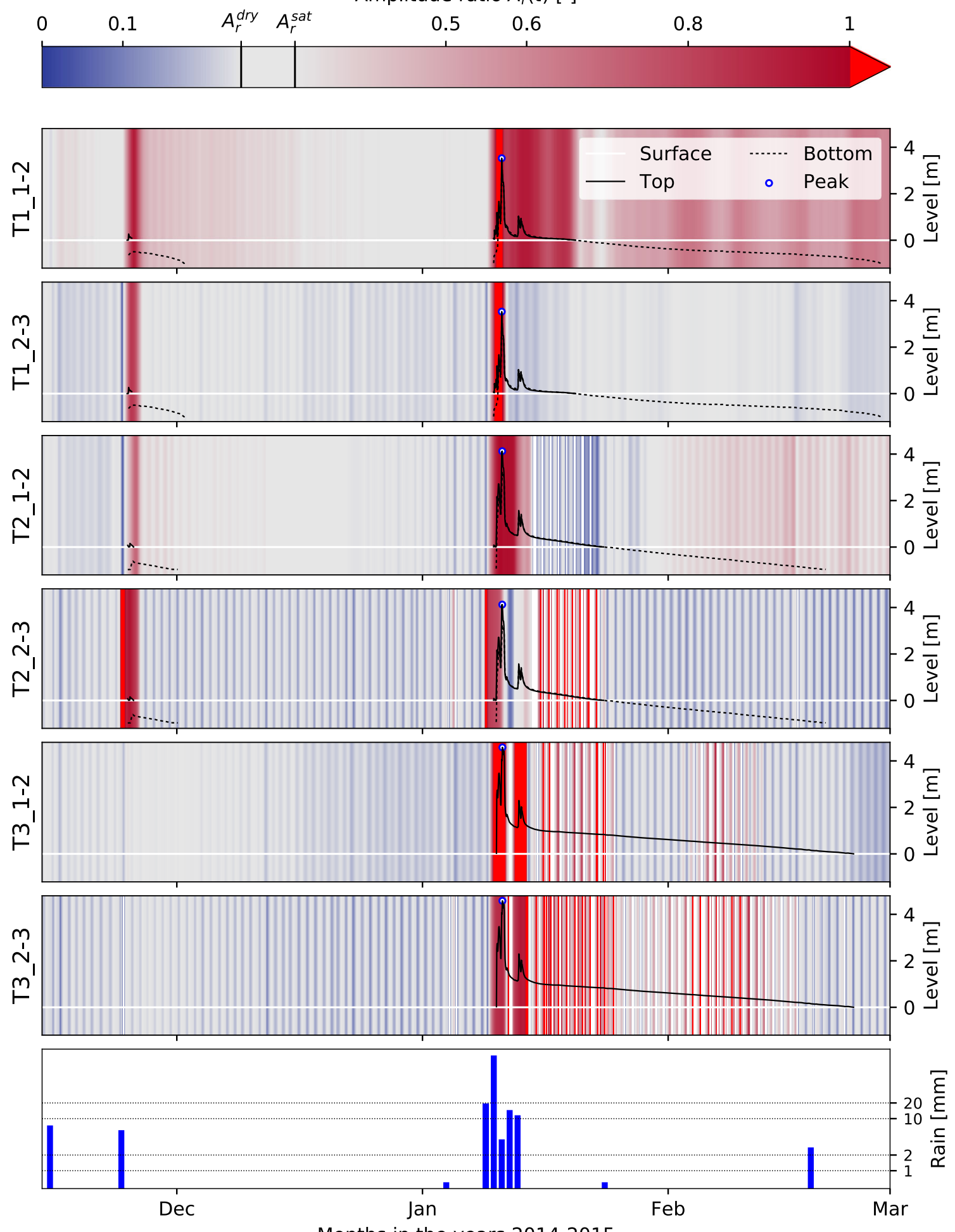

Months in the years 2014-2015

Fig. 11 Amplitude ratios for the streambed arrays (T1, T2 and T3) at the intervals $1-2$ and $2-3$, interpreted from the temperature measurements and plotted as colour stripes. Each colour stipe represents the Fourier transformed amplitude ratio averaged over a 3-day period. The water levels are shown on top (in black) for reference with the peak of individual runoff events marked for identification. The individual rainfall events are shown in the bar graph at the base of the figure. Note that this bar graph has a logarithmic scale with the $20-\mathrm{mm}$ threshold that is associated with a runoff-producing event shown for reference 
flow before a return to downward flow until the top hydraulic head sensor indicates that the surface becomes dry.

- T1 2-3: As for the upper T1 sensor but with slightly longer period of nonvertical flow before a change to weak upward flow $\left(0.15<A_{\mathrm{r}}<A_{\mathrm{r}}^{\text {dry }}\right)$ which slowly subsided until the creek bed dried.

- T2_1-2: Downward flow until the end of the storm event and then switching to increasing upward flow.

- T2_2-3: A shorter period of downward flow at the beginning of the storm followed by a brief period of upward flow before switching to downward flow until the stream dries.

- T3_1-2: Nonvertical flow is indicated throughout the storm event (10-11 January) being reactivated by the later rain on (13 January). There was a dry period on the 12th of January during which the flood receded and the nonvertical flow stopped. After a few days, water started moving down again (red colour).

- T3_2-3: Very similar to the upper sensor with the difference that downward rather than non vertical flow is indicated at the start of the storm and is followed by stronger downward flow, interrupted by upward flow before later downward flow. Note that T3 had surface water for a much greater time period than at T1 or T2. This is possibly the result of drainage of water from overbank locations flooded during the height of the storm when the water level reached $4.5 \mathrm{~m}$ depth.

\section{Hydrochemistry and estimated groundwater ages}

The hydrochemical field measurement data are presented in Table 3 and the full chemical analyses are given in Table 4 . Except for borehole FG79, which has a charge balance error of $5.5 \%$, all other samples have charge-balance errors below
5\%. Older water analysis data from 1967 and 1981 from the Planet Camp Borehole and Mandelman Borehole were added to this study from Beavis and Beavis (1984).

All the groundwater samples are fresh to slightly brackish, with a larger variation for the shallow samples. Even the fresher samples still have a relatively high ion content with EC higher than $1,850 \mu \mathrm{S} / \mathrm{cm}$. Most of the samples are a Na-Cl water type with some of the shallow samples (FG78-1, FG79 and FG82-1) tending towards a mixed $\mathrm{Na}-\mathrm{Ca}-\mathrm{Mg}-\mathrm{Cl}-\mathrm{HCO}_{3}$ water type. The deeper samples from the water supply bore of Smith's and Dawson's have a significantly lower $\mathrm{Ca}-\mathrm{HCO}_{3}$ content than the shallower samples.

\section{Environmental isotopes}

The environmental isotope analyses for water sampled in November 2016 are given in Table 5. As noted above, it was not possible to sample all the boreholes during this field campaign. The general pattern is the deeper water supply bores of Smith's and Dawson's being tritium free $(<0.01$ $\mathrm{TU})$ and low in ${ }^{14} \mathrm{C}$-DIC (2.78 and $\left.5.06 \mathrm{pMC}\right)$. In contrast, the shallow bores had modern water with ${ }^{14} \mathrm{C}$-DIC 103.3 and $104.5 \mathrm{pMC}$ and measurable tritium values of 0.5 and $0.8 \mathrm{TU}$, which could be derived over the course of two tritium halflives from the value of $3.2 \mathrm{TU}$ observed in the creek at the time of sampling.

\section{Discussion}

\section{Rainfall rates and runoff thresholds}

It is apparent from Table 1 that rainfall rates frequently exceed the maximum infiltration rate of the soils leading to rapid

Table 3 Field chemical data

\begin{tabular}{llllrlll}
\hline Borehole & Depth $(\mathrm{m})$ & DO $(\mathrm{mg} / \mathrm{L})$ & Fluid EC $(\mu \mathrm{S} / \mathrm{cm})$ & Eh $(\mathrm{mV})$ & $\mathrm{pH}$ & Temperature $\left({ }^{\circ} \mathrm{C}\right)$ & Alkalinity $(\mathrm{meq} / \mathrm{L})$ \\
\hline FG79 & 20 & 0.59 & 2,499 & 52 & 6.82 & 25.1 & 10.48 \\
Smith's Borehole & 120 & 0.22 & 2,081 & -80 & 7.07 & 25.0 & 4.15 \\
Dawson's Borehole & 120 & 0.01 & 2,567 & -223 & 7.05 & 25.4 & 3.40 \\
FG82-1 & 15 & 3.82 & 1,850 & 109 & 6.63 & 25.6 & 6.97 \\
FG78-1 & 17 & Anoxic & 4,866 & - & - & - & 10.16 \\
Fowler's Gap Creek & 32 & 9.38 & 4,682 & 112 & 8.07 & 26.9 & 4.16 \\
Planet Camp Borehole '81 & 110 & - & 2,820 & - & - & - & - \\
Mandelman borehole '67 & 94 & - & 3,492 & - & - & - & - \\
Mandelman Borehole '81 & 95 & - & 4,300 & - & - & - & - \\
New Sandstone borehole NSB1 & 116 & - & 6,290 & - & 6.64 & - & - \\
New Sandy Creek NSG3 & 101 & - & 3,930 & - & 6.74 & -
\end{tabular}

Notes: FG78-1 ran dry during sampling. Chemical data for the Planet Camp, Mandelman's, New Sandstone and Sandy Creek boreholes are from Beavis and Beavis (1984). Depths refer to the mid-point of the screen if known, or to the total depth 
Table 4 Chemical data for the Planet Camp, Mandelman's, New Sandstone and Sandy Creek borehole are from Beavis and Beavis (1984). Borehole locations are shown in Fig. 4

\begin{tabular}{lllllllll}
\hline Borehole & $\mathrm{Ca}(\mathrm{mg} / \mathrm{L})$ & $\mathrm{Mg}(\mathrm{mg} / \mathrm{L})$ & $\mathrm{Na}(\mathrm{mg} / \mathrm{L})$ & $\mathrm{K}(\mathrm{mg} / \mathrm{L})$ & $\mathrm{Sr}(\mathrm{mg} / \mathrm{L})$ & $\mathrm{Cl}(\mathrm{mg} / \mathrm{L})$ & $\mathrm{SO}_{4}(\mathrm{mg} / \mathrm{L})$ & $\mathrm{HCO}(\mathrm{mg} / \mathrm{L})$ \\
\hline FG79 & 131 & 67.0 & 228 & 3.98 & 1.60 & 439 & 79 & 639.5 \\
Smith's Borehole & 67.2 & 41.0 & 268 & 5.65 & 0.87 & 389 & 224 & 253.2 \\
Dawson's Borehole & 85.2 & 55.6 & 311 & 6.75 & 1.08 & 526 & 275 & 207.5 \\
FG82-1 & 149 & 32.8 & 173 & 4.18 & 0.76 & 333 & 60 & 425.3 \\
FG78-1 & 267 & 172 & 434 & 7.85 & 3.41 & 1,152 & 6.2 & 619.9 \\
Fowler's Gap Creek & 268 & 125 & 479 & 13.03 & 2.08 & 969 & 555 & 253.8 \\
Planet Camp '81 & 20 & 33 & 402 & 7 & - & 426 & 262 & 254 \\
Mandelman '67 & 115 & 25 & 667 & 8 & - & 829 & 401 & 210 \\
Mandelman '81 & 62 & 43 & 605 & 12 & - & 780 & 400 & 250 \\
New Sandstone borehole NSB1 & 210 & 60 & 980 & 15 & - & 1,500 & 180 & 320 \\
New Sandy Creek borehole NSG3 & 120 & 15 & 610 & 5 & - & 925 & 60 & 95
\end{tabular}

runoff. Cordery et al. (1983) noted that the onset of flow down a creek at Fowlers Gap was directly related to the porosity of the unsaturated alluvium in the creek bed. Once the alluvium was fully saturated, then surface flow commenced. The results of this study do not support this contention, at least for large storms with many intense bursts. Of the 23 runoff events recorded at the Homestead Creek level gauge, 6 events occurred after rainfall of between 10 and $15 \mathrm{~mm}$ and 12 events occurred after less than $20 \mathrm{~mm}$ of rain. For example, $6 \mathrm{~h}$ after the initial rainfall at Homestead Creek and after $7 \mathrm{~h}$ duration and $20 \mathrm{~mm}$ of rain falling in the larger Fowlers Gap Creek catchment, runoff at the gauging station was recorded. The data is a little variable but it is apparent that $10-20 \mathrm{~mm}$ can be taken as the approximate threshold to produce runoff.

The maximum rainfall rate recorded in the 5-year period between 2013 and 2016 at the tipping-bucket gauges was $7.4 \mathrm{~mm}$ in $10 \mathrm{~s}$ at Bald Hills in the Devonian Sandstone country (station 5 on Fig. 1) and $28.2 \mathrm{~mm}$ in $15 \mathrm{~min}$ at Warren's Tank on the plains to the east (station 4 in Fig. 1). These intensities are much larger than the maximum rates recorded during the January storm of approximately $0.4 \mathrm{~mm}$ (Table 1) in $10 \mathrm{~s}$ and represent storm bursts from cumulonimbus cells that occurred at other times. No extensive studies of soil hydraulic conductivity have been performed at the site but high clay contents in the soils are likely to minimise direct infiltration and the potential for diffuse recharge as noted by Acworth et al. (2016a).

\section{Lack of groundwater level response in the deeper aquifer}

The two deep boreholes (FG86 and FG82-2) are considered to be entirely confined by the layer of stiff grey and red clay indicated by the high bulk electrical conductivity layer seen in Fig. 5. This conclusion is supported by the BRF calculated from the regression deconvolution which shows a barometric efficiency of $>0.95$ for FG86 and 0.75 for FG82-2. The latter is smaller than the results calculated by Acworth et al. (2016b) for a different time period possibly due to the difference in methodology as discussed in Turnadge et al. (2019). There is

Table 5 Environmental tracer data

\begin{tabular}{|c|c|c|c|c|c|c|c|}
\hline \multirow[t]{2}{*}{ Borehole } & \multirow{2}{*}{$\begin{array}{l}\delta^{13} \mathrm{C} \\
(\%)\end{array}$} & \multicolumn{2}{|l|}{${ }^{3} \mathrm{H}$} & \multicolumn{2}{|l|}{${ }^{14} \mathrm{C}$-DIC } & \multicolumn{2}{|l|}{ Years BP } \\
\hline & & $\begin{array}{c}{ }^{3} \mathrm{H} \text { value } \\
(\mathrm{TU})\end{array}$ & $\begin{array}{l}\text { Uncertainty } \\
(\mathrm{TU} \pm)\end{array}$ & $\begin{array}{l}{ }^{14} \mathrm{C}-\mathrm{DIC} \text { value } \\
(\mathrm{pMC})\end{array}$ & $\begin{array}{l}\text { Uncertainty } \\
(\mathrm{pMC} \pm)\end{array}$ & $\begin{array}{l}\text { Years BP value } \\
\text { (Years) }\end{array}$ & $\begin{array}{l}\text { Uncertainty } \\
\text { (Years } \pm \text { ) }\end{array}$ \\
\hline FG79 & -14 & 0.5 & 0.04 & 103.31 & 0.26 & Modern & - \\
\hline FG82-1 & -15 & 0.8 & 0.05 & 104.48 & 0.26 & Modern & - \\
\hline FG78-1 & - & - & - & - & - & - & - \\
\hline Smith's borehole & -11.1 & 0.01 & 0.03 & 5.06 & 0.06 & 23,960 & 110 \\
\hline Dawson's borehole & -11.4 & 0.01 & 0.03 & 2.78 & 0.04 & 28,780 & 130 \\
\hline FG Creek & -7.9 & 3.2 & 0.15 & 99.35 & 0.27 & 50 & 25 \\
\hline
\end{tabular}

Notes: FG78-1 ran dry during sampling. The groundwater age years before present (BP) is the conventional uncorrected age, as reported by the laboratory 
no significant variation or overall net change in head over the 6-year investigation period (Fig. 8 and Fig. S4 of the ESM). The lack of response at any time confirms the isolation of this deeper aquifer from the shallower system and explains the Late Pleistocene age date of groundwater drawn from both Smith's Bore and Dawson's Bore which are both close to FG86 and FG82 with their screens set at similar depths (Fig. S2 of the ESM). Abstraction from these bores caused small $(50 \mathrm{~mm})$ responses in the observation bores that can be observed in the plots shown in Fig. 8 but not in Fig. S4 of the ESM, indicating the success of the BRF in suppressing the atmospheric signal in the groundwater hydrographs.

\section{Streamflow, flood-wave and infiltration processes}

The streambed water level records obtained from the temperature arrays clearly document streamflow events with a higher temporal and spatial resolution than previously measured at this location. They demonstrate that the speed of the flood wave in Fowlers Gap Creek increased from $0.53 \mathrm{~km} / \mathrm{h}$ $(0.15 \mathrm{~m} / \mathrm{s})$ between T0 and T1 to $4.66 \mathrm{~km} / \mathrm{h}(1.3 \mathrm{~m} / \mathrm{s})$ between T5 and T6 (Table 2). The increase in flood front speed was likely caused by the increasing volume of the flood and the decrease in sinuosity of the flood channel. Dunkerly (2008) also calculated from theoretical consideration of the channel width and observed roughness that the stream velocity varies with faster flow in flow chutes where mean flow could reach $2.8 \mathrm{~m} / \mathrm{s}$ (range 1.66-4.39 m/s), while in the nonchute reaches, the mean flow was $1.47 \mathrm{~m} / \mathrm{s}$.

The record of hydraulic head in borehole FG77 installed close to the stream channel (Fig. 9) demonstrates that there was no immediate increase in water level in the borehole in response to the onset of flow in the creek, despite the ground surface around the borehole becoming inundated. The bubbler gauge and the temperature array show (Fig. 9) surface flow commencing just before midnight $(23: 45)$ on the 9th of January, whereas the rise in head at FG77 does not begin until the bore is overtopped at the height of phase 3 of the storm at approx. 22:00 on the 10th of January. The delayed response is emphasised by the ellipse in Fig. 9.

This observation was a little surprising as the top of the borehole screen was only approx. $1.5 \mathrm{~m}$ beneath the stream bed (Table S1 of the ESM) and the area around the borehole was completely inundated to a depth of approx. $0.5 \mathrm{~m}$ (Fig. 9) for approx. $20 \mathrm{~h}$ before the overtopping occurred. Intuitively, water would be expected to commence downward movement into the sediment shortly after a positive head gradient was generated by the flood, as observed by Blasch et al. (2006). This lack of response, that was also observed at FG79 and FG75, indicates that infiltration into the floodplain sediments and streambanks is a very slow process in comparison with the filling of the highly permeable shallow alluvium that forms the stream bed, and which filled within minutes as evidenced by the stream-bed temperature/pressure arrays.

There was a large potential for streambed water infiltration, as indicated in Fig. 10, particularly between the top sensor and the next sensor $0.29 \mathrm{~m}$ below. However, the VHG's demonstrated an interesting behaviour-for example, VHG's were largest right at the beginning of the flood when heads were transient and slowly decreased even though the average water level at the surface rose. As the event progressed there were a few short term downward VHG spikes coincident with rapid surface water level increases. Towards the end of the flood, the VHG's become upward during the flood recession and remain stable indicating discharge of groundwater into the stream. This behaviour was considered more typical of bank storage in perennial streams and was surprising for the ephemeral Fowlers Gap Creek. This indicated that the infiltrated water had been held on top of lower permeability layers either in the streambed at higher elevation further upstream or in the banks. The receding surface-water level allowed it to discharge back into the stream.

The temperature amplitudes provided independent evidence for water infiltration and downward flow within the shallow near-surface sediments along Fowlers Gap creek, at least at the beginning of each flow event as indicated by the red colour in Fig. 11. Further, the daily temperature amplitudes in T2 and T3 again showed downward flow when the water level detected by the bottom level sensor started to rapidly fall. As a final observation, amplitude ratios in intervals 2-3 for both locations showed water infiltration in response to rainfall but in the absence of streamflow.

The amplitude ratio colours of $\mathrm{T} 1$ showed continuous downward flow after the big flood when there was an absence of water as indicated by the level response. It was believed this may have been an artefact due to erosion of sediments. Further, at T2 after the flood, the amplitude ratios indicated an apparent upward flow in the absence of water as evidenced by the level sensors. It was possible that the diminished amplitudes could have been a result of cooling from evaporation of the water from the many small rainfall events, as sediment deposition could be excluded as an explanation since there was no surface water flow. It was also possible that this upward flow represented water movement in response to evapotranspiration, at least at T2. However, further analysis and discussion of processes that may affect the calibration of amplitude ratios in the unsaturated zone is beyond the scope of this paper.

\section{Hydrochemistry and environmental tracers}

\section{Hydrochemistry}

Only one set of hydrochemical sample data was available and that only from a limited number of sample sites. Considerable 
uncertainty must therefore exist in the interpretation of this data on a regional basis. However, some general observations can still be made. It is possible to rule out connectivity between the shallow aquifer (represented by FG82-1) and the deeper aquifer that supports groundwater extraction for water supply (represented by Smiths and Dawson's bores). For example, it is very hard perceiving $\mathrm{Ca}$ and $\mathrm{HCO}_{3}$ being removed by water-rock interactions to create the observed decrease in these ions from the shallow to the deeper aquifer (Table 4), especially since the SI for calcite indicated sub-saturation around -0.3 , which should preclude precipitation of calcite. The separation between the two zones is indicated both geophysically (Fig. 5) and hydraulically (Fig. 8) and the hydrochemical data compliments these findings discussed in the preceding. Therefore, the deeper groundwater must have recharged from a different (remote) source through rocks with a low mineral carbonate content or during times with very different climatic and/or biogeochemical conditions (i.e. lower soil $\mathrm{CO}_{2}$ partial pressure and therefore less total dissolved inorganic carbon in the deep aquifer).

\section{Tritium ages}

In terms of tracers, the shallow groundwater (FG79 and FG821) samples have a modern signature with an ${ }^{3} \mathrm{H}$ average of about 0.65 TU and ${ }^{14} \mathrm{C}$ average of about $104 \mathrm{pMC}$ (uncorrected). The high ${ }^{14} \mathrm{C}$ values preclude dilution with radio-dead carbon from mineral dissolution or mixing with older radiocarbon decayed groundwater. Because of this lack of mixing with old groundwater, the observed groundwater tritium values must be a result of radioactive decay. However, establishing exact groundwater ages at FGAZRS from the groundwater tritium data is uncertain, since there are no local tritium rainfall records. The nearest locations with historic rainfall tritium records are: Adelaide, $510 \mathrm{~km}$ to the southwest; Charleville $672 \mathrm{~km}$ to the northeast; and Alice Springs approx. $1,100 \mathrm{~km}$ to the north west.

Tadros et al. (2014) provide a comprehensive review of Australian rainfall tritium records, where they show that the rainfall tritium values are highly variable over both space and time. They show that beside the elevated tritium due to atmospheric thermonuclear bomb testing in the 1960s, tritium is elevated in rainfall with increasing latitude (south) and due to a continental effect with higher activities towards the centre of Australia. Seasonally higher values have been measured in the Australian spring by about a factor of two and finally they show that there is an amount effect where large rainfall events are depleted in tritium particularly at inland sites. In the recent two decades tritium values in southeast Australia have stabilised at natural background values of 2-3 TU.

Given these uncertainties in historic rainfall tritium values for southeast Australia, it is more sensible to look for years of high rainfall (Fig. 2) at FGAZRS that may be potential years in which the groundwater recharge could have occurred. It is then possible to back calculate what the tritium concentration would have been for those years, based upon the measured values in 2016 and using the radioactive decay function for tritium (half-life of 12.32 years). The years 1974, 1987, 2010, 2011 and 2016 have rainfall above the annual rainfall mean plus 1 standard deviation (Fig. 2) and these were considered as possible wet years that could have generated recharge.

Tadros et al. (2014) have produced maps of tritium in Australian rainfall for the years 1973/1974 and the period 2005 to 2011. Because Alice Springs lies in the direction from which heavy rainfall has been reported to have travelled, that station was selected to represent FGAZRS rainfall rather that the coastal, but closer, site of Adelaide.

In 2016, the observed tritium values $\left(A_{\mathrm{t}}\right.$ values in the decay equation) were $0.5 \mathrm{TU}$ for FG79 and 0.8 TU for FG82-1 (Table 6). Rearranging the decay equation for $A_{0}$ and solving for the possible elapsed times when rain fell and recharge could have occurred gives the $A_{0}$ values shown in Table 6 .

The rainfall tritium values for Alice Springs and FGAZRS have been extrapolated from maps in Tadros et al. (2014). These data are given in Table 7 . The observed tritium values $\left(A_{\mathrm{t}}\right)$ in 2016 were $0.5 \mathrm{TU}$ at FG79 and $0.8 \mathrm{TU}$ at FG82-1. For these values to represent radioactive decay over the 6 years since 2010 , the initial tritium values $\left(A_{0}\right)$ would have been $0.70 \mathrm{TU}$ at FG79 and 1.12 TU at FG82-1. These values are well below the measured values reported by Tadros et al. (2014) and imply that the rainfall in 2016 or 2010/2011 could not be the source of recharge at FG79 and FG82-1.

Rainfall in 1987 is reported by Tadros et al. (2014) to have had a tritium concentration of approx. 5.0 at Alice Springs. If it is assumed there was a similar pattern of increased tritium at FGAZRS of perhaps 20\% over Alice Springs then an approx.

Table 6 Possible tritium concentrations (TU) at source $\left(A_{0}\right)$ determined by back-solving the tritium decay equation for the different elapsed times when recharge could have occurred

\begin{tabular}{llllll}
\hline Borehole & $\begin{array}{l}\text { Observed tritium } \\
\text { concentration }\left(A_{\mathrm{t}}\right) \text { in } \\
2016(\mathrm{TU})\end{array}$ & $\begin{array}{l}\text { Possible tritium } \\
\text { concentration }\left(A_{0}\right) \text { after } \\
1 \text { year }(\mathrm{TU})\end{array}$ & $\begin{array}{l}\text { Possible tritium } \\
\text { concentration }\left(A_{0}\right) \text { after } \\
6 \text { years }(2010)(\mathrm{TU})\end{array}$ & $\begin{array}{l}\text { Possible tritium } \\
\text { concentration }\left(A_{0}\right) \text { after } \\
29 \text { years }(1987)(\mathrm{TU})\end{array}$ & $\begin{array}{l}\text { Possible tritium } \\
\text { concentration }\left(A_{0}\right) \text { after } \\
42 \text { years }(1974)(\mathrm{TU})\end{array}$ \\
\hline FG79 & 0.5 & 0.53 & 0.70 & 2.56 & 5.31 \\
FG82-1 & 0.8 & 0.85 & 1.12 & 4.09 & 8.50 \\
\hline
\end{tabular}


Table 7 Observed results $\left(A_{\mathrm{t}}\right)$ for tritium in rainfall for Alice Springs and extrapolated for FGAZRS using the maps in Tadros et al. (2014). Data for 1987 are from a figure showing results for Alice Springs

\begin{tabular}{llll}
\hline Location & $2005-$ & 1987 & $\begin{array}{l}1973- \\
1974\end{array}$ \\
\hline Alice Springs & 2011 & & 10.5 \\
FGAZRS & 2.5 & 5.0 & 14.0 \\
\hline
\end{tabular}

$A_{0}$ for FGAZRS would have been 6.0 TU. This compares with the possible values for $A_{0}$ (Table 6) after 29 years of 2.56 or 4.09. Both these values appear low but given the uncertainties of the analysis, 1987 should be considered a possible source year for recharge based on the tritium data alone. However, when the fact that the rainfall in 1987 was concentrated in a single storm event (Fig. 12) and considering the observations of a similar event in 2015 producing little recharge, 1987 is unlikely to be the source of the tritium observed in FG79 and FG82-1.

The multiple rainfall events in 1973-1974 (Fig. 12) are considered likely to have produced multiple recharge pulses based upon the observations presented in this paper. The tritium data is consistent with this analysis. Possible tritium concentrations $\left(A_{0}\right)$ in 1974 were 5.31 or 8.50 (Table 6) and compare well with estimates of $A_{0}$ based upon observation (Tadros et al. 2014 in Table 7) given the uncertainties of the actual tritium concentrations at the time.

While it is acknowledged that the observed tritium values could also represent mixing between older water and modern water, which could complicate the analysis, the observed ${ }^{14} \mathrm{C}$ values of about $104 \mathrm{pMC}$ in the same bores do not allow for much mixing to dilute the tritium data. In summary and on the balance of probabilities, the data are consistent with the sampled water being recharged during multiple events in 1974. However, it is also noted that this does not preclude recharge having occurred during 2010-2011 or 2016 as groundwater recharged then may be present within the unsaturated profile above the screen depth (Table S1 of the ESM) or was not removed during sampling from the overlying column of water.

\section{Radio-carbon ages}

The deeper groundwater $(\sim 80 \mathrm{~m})$ is free of measurable tritium and has a pMC of about $4 \%$ or an average uncorrected ${ }^{14} \mathrm{C}$ age
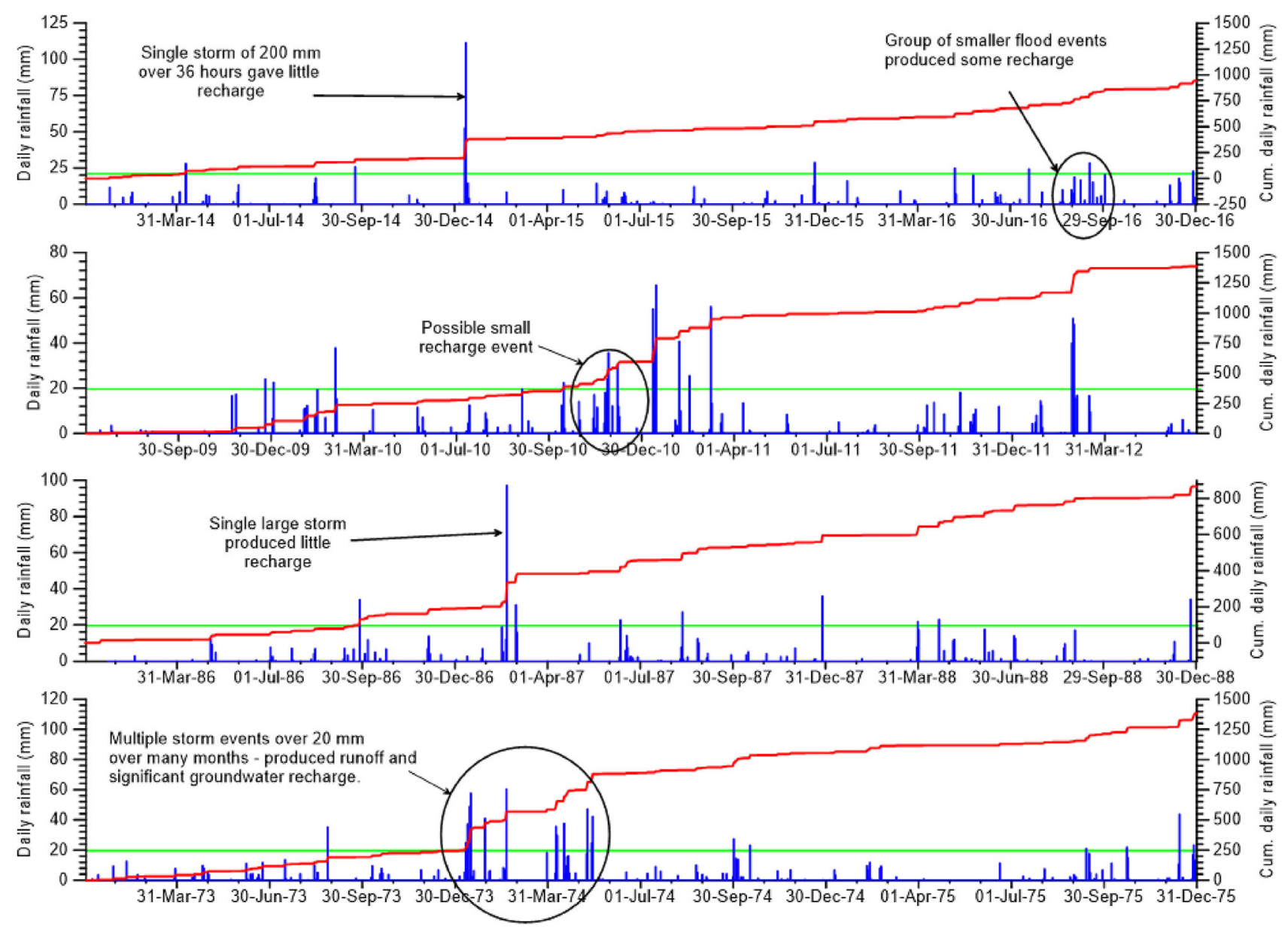

Fig. 12 Daily rainfall totals (mm) for the four periods: 1973-1975, 1986-1988, 2009-2010 and 2014-2016. The green bar indicates the approx. Threshold for flood flow in Fowlers Gap Creek 
of about 26,400 years. As there could be a considerable contribution from radiocarbon dead material these ages could be overestimated. With the observed decrease in alkalinity from the shallow aquifer to the deeper aquifer from 9.20 to $3.8 \mathrm{meq} /$ $\mathrm{L}$ it is not possible to carry out dissolved inorganic carbon mass-balance corrections based on measured dissolved inorganic carbon or alkalinity. Instead, corrections can be made based on a $\delta^{13} \mathrm{C}$ mixing model using end-member $\delta^{13} \mathrm{C}$ values for the soil solution and carbonate minerals. Two different corrections were made: one that uses an estimated $\delta^{13} \mathrm{C}$ value of $-23 \%$ for the soil solution (Clark and Fritz 1997); and one that uses the difference in $\delta^{13} \mathrm{C}$ from the shallow to the deep aquifer (see Table 5) assuming a local pathway or similar conditions at a distant recharge location. Both models use a value of $0 \% \circ \delta^{13} \mathrm{C}$ for dissolving carbonate minerals. The calculations (Table 8) give corrected radiocarbon ages ranging from (18,700-27,500 years) revealing that the corrections lead to relatively small changes in the ages due to the nature of the 1 st order radioactive decay curve. More sophisticated correction models can be applied but it is hard to perceive that the deeper groundwater samples are anything but old even with more extreme corrections. The ${ }^{14} \mathrm{C}$ data therefore either represents a system with very limited local recharge of this deeper aquifer or more likely remote recharge of a larger regional confined aquifer with slow lateral groundwater flow. This conclusion is consistent with the geophysical, hydraulic and hydrochemical inferences discussed in the preceding.

\section{The complexity of recharge processes}

\section{Possibility of direct recharge}

Diffuse recharge at FGAZRS was not anticipated due to the observations of a high clay content in the soil and the very rapid runoff generation (Acworth et al. 2016a). The desiccation of the soil under conditions where no rainfall occurs for several months leads to a low-hydraulic conductivity layer developing which is likely to further inhibit infiltration and diffuse recharge. The high rainfall intensities combined with a large soil moisture deficit and the low hydraulic conductivity ensure that the great majority of rainfall that occurs is shed as overland flow to become runoff available for potential focussed recharge. This is particularly so where the soils are very shallow as on the Precambrian rocks to the west of the Nundooka Fault but also evident on the silty top soil on the plains to the east.

\section{Focused recharge}

The period during which the creeks record flow or have saturated alluvial channel sands, marks the period when focused, indirect, recharge into the shallow underlying sediments would be expected to have occurred. Focused, localised, recharge may also occur on the sandstone outcrops as the result of infiltration into fractures. It is noted that Sandy Creek (Fig. 4) flows through the sandstone hills area frequently over outcropping rock. This type of indirect recharge is also likely responsible for the recharge into the deeper aquifers and is discussed further in the following.

\section{Potential consequences of entrapped air in the stream bed}

A lack of sustained downward flow below the river bed sediment at transects 1 and 2 has been identified from the temperature arrays (Fig. 11) and from the borehole hydrographs for FG75 (not presented) and FG77 (Fig. 9). This requires explanation.

The top 4-5 m of clay and gravel in the creek bed and the adjacent flood plain (Fig. 6) were dry (air-filled porosity) before the flood. Significant clay rich horizons were also observed while installing the temperature sondes. The flood moved at an average speed of approximately $1.64 \mathrm{~km} / \mathrm{h}$ and the depth of flood water then rapidly increased (Fig. 10). Downward movement of water from the base of the shallow alluvial zone is indicated by the streambed arrays for the top two sensors (T1_1-2) shown in Fig. 11 but this is only in the top $300 \mathrm{~mm}$. Below this, there is no indication of any sustained water movement between the sensors (T1_2-3) as clearly seen in Fig. 11 by the change from downward flow (marked in red) to upward flow (marked in blue). Under these conditions it can be assumed that, after initially quickly filling pockets of higher permeability superficial sandy deposits, the flood water was moving over the top of lower permeability material. It also seems clear that there would have been very great variations in hydraulic conductivity in the creek bed as the result of layers of cobbles and clay being present. Hence,

Table 8 Correction models for ${ }^{14} \mathrm{C}$ dating using estimated $\delta^{13} \mathrm{C}$ value of $-23 \%$ of soil the soil solution and a value of $0 \%$ o ${ }^{13} \mathrm{C}$ for dissolving carbonate minerals (Clark and Fritz 1997). pMC percentage modern carbon

\begin{tabular}{lllllll}
\hline Borehole & ${ }^{14} \mathrm{C}(\mathrm{pMC})$ & $\begin{array}{l}\text { Conventional age } \\
\text { (years) }\end{array}$ & $\begin{array}{l}\text { Correction }(q) \text { for soil } \\
\delta{ }^{13} \mathrm{C} \text { end-member }\end{array}$ & $\begin{array}{l}\text { Corrected ages soil } \\
\text { end-member (years) }\end{array}$ & $\begin{array}{l}\text { Correction }(q) \text { shallow } \\
\mathrm{GW} \delta^{13} \mathrm{C} \text { end-member }\end{array}$ & $\begin{array}{l}\text { Corrected ages for shallow } \\
\mathrm{GW} \text { end-member }(\mathrm{years})\end{array}$ \\
\hline Smith's borehole & 2.78 & 28,780 & 0.49 & 23,670 & 0.77 & 27,484 \\
Dawson's borehole & 5.06 & 23,969 & 0.49 & 18,718 & 0.77 & 22,532 \\
\hline
\end{tabular}


any wetting front that developed would have had a complex three-dimensional (3D) distribution with most flow occurring through connected higher permeability material but leaving zones of unsaturated lower hydraulic conductivity material until water could move into these zones by capillary action.

Figure 11 provides a comprehensive and multi-parameter presentation of the dynamics of water flow in near surface sediments developed by Rau et al. (2017); however, interpretation of the heat tracing results is limited to water saturated conditions. More information about the spatio-temporal flow processes could be derived by further developing methods accounting for variably saturated conditions, as presented in Halloran et al. (2016).

The combined impact of the air-filled porosity and the layers of clay significantly reduces the vertical hydraulic conductivity of the sand and gravel (Bianchi and Haskell 1996; Faybishenko 1995; Wang et al. 1998). Faybishenko (1995) reports detailed experiments on loamy soils that show that the hydraulic conductivity of material can be reduced by a factor of between 5 and 8 when initially air-filled. This work was carried out on loamy soils where the saturated hydraulic conductivity will be much higher than the high clay content sand and gravel observed during the investigations at FGAZRS.

To explain the lack of response in some of the shallow piezometers, it is proposed that flood water is required to produce a downward hydraulic gradient for many days to allow sufficient time for infiltration to occur through layers of lower permeability and before entrapped air can be dissipated or dissolved, before widespread focused recharge can occur at this location.

\section{Evidence for indirect recharge at transects 2 and 3}

Although no evidence of recharge beneath the creek was observed at FG77 on the first transect, there are small responses that occur in the shallow piezometers in the second and third transects that indicate some recharge through the stream bed further down the creek. The record for FG82-1 shows the clearest response that commenced after the major flood in January 2015 and appears to have arrested the previously occurring recession in head. Similar but more muted responses are seen (Fig. 8) in FG78-1 and FG79. In FG78-2 there is a similarly timed but muted increase in the head. This response appears to die away in FG82-1 after approx. 11 months before a repeated sequence of smaller (than January 2015) floods over 5 weeks in the spring (Fig. 12) of 2016 again causes recharge to occur. Significantly, this sequence of smaller floods (top panel in Fig. 8) caused recharge that appears to have produced a greater response in FG82-1 (Fig. 8) than the earlier major flood in 2015. Both periods of recharge seen in FG82-1 did not change the overall decline in head that was evident in the record, indicating that the groundwater response time for this groundwater system is relatively large and that the recessions are integrating the hydraulic responses to recharge over at least a multi-decadal period (Cuthbert et al. 2019b).

Long term average recharge is expressed in the background rate of a straight-line groundwater recession (Cuthbert 2014). The recession is clearly seen in Fig. 8 and Fig. S4 of the ESM. The rate is approximately $0.6 \mathrm{~m} /$ year for FG79 and $0.7 \mathrm{~m} /$ year for FG82-1 and is equivalent to the long-term recharge divided by the specific yield (see Cuthbert et al. (2016) for explanation of how this process and method works in more detail). Assuming the bulk specific yield of the heterogeneous sandclay sediments is, say, $2-4 \%$, this amounts to a long-term (averaged over multiple decades) recharge of approximately $10-20 \mathrm{~mm} /$ year. However, over what spatial extent or temporal period this estimate is valid for is not possible to ascertain without additional data from piezometers more distant from the creek. FG80 was intended to provide some information but only proved the inhomogeneity of the deposits away from the creek (100 m distant) and the electrical image line (Fig. 6) shows further detail of this inhomogeneity.

The head response to the storms in 2015/2016 was approximately $0.6 \mathrm{~m}$ in FG79 and $0.9 \mathrm{~m}$ in FG82-1 (Fig. 8) after accounting for the observed background recession rate during dry periods. Hence, one can estimate that over the long term, recharge must be approximately twice that per year of the recharge that occurred in 2015-2016. The tritium data at FG86-1 and FG79 indicate that a likely contribution was from the multiple flood events in 1974 (Fig. 12). It is also noted that the floods in 2010 and 2011 (Fig. 12) contained several single storms and groups of small storms and that these may have produced substantial recharge. A wetter period in 1987 (Figs. 2 and 12) was related to a single large storm and therefore may have only contributed a smaller than average recharge for the same reasons as the limited recharge produced during the 2015 storm.

\section{Indirect recharge onto the sandstones}

The water level in the sandstone at the old sandstone bore (Fig. 4 shows the location) occurs at approximately $100.5 \mathrm{~m}$ bgl (in November 2016). Records show that the original level when the borehole was drilled in 1954 (the date is unsure, Beavis and Beavis 1984) was $97.5 \mathrm{~m} \mathrm{bgl}$, this despite the fact that the bore is regularly pumped with a yield of approximately $0.5 \mathrm{~L} / \mathrm{s}$ (estimated to be approx. $5,000 \mathrm{~m}^{3} /$ year). The old bore was abandoned in 1980 and a new abstraction bore drilled $8 \mathrm{~m}$ away. This bore has a very similar level and the old bore responds to pumping from the new bore, proving that extensive fracturing exists in the sandstones at depth. These fractures are reported to extend to the surface (Beavis and Beavis 1984) and the creek flows over outcropping sandstone for several kilometres (Figs. 3 and 4). 
The fact that the water level in these bores is relatively unchanged over more than 50 years of intermittent pumping can be taken to infer that the groundwater system is in steady state where the abstraction is balanced by another source of water. This could be indirect recharge on the sandstone hills or leakage from a more localised source of water; however, there must be a source of water that supports the abstraction from Smith's borehole where the age of the water has been dated at $\sim 24 \mathrm{ka}$. It is also noted that extensive fresh groundwater at depths between 830 and $1,220 \mathrm{~m}$ has been identified in the Bancannia Basin sediments to the south east of FGAZRS and these are directly contiguous with the sandstones around the bores in the sandstone outcrop. It has been suggested that the deep aquifer is worthy of development in this otherwise arid environment, but development must be preceded by a better understanding of the recharge and groundwater flow paths and processes to allow informed groundwater management (Gleeson et al. 2020).

It is noted that the period before the last glacial maximum (26-22 ka) has been identified as one of both reduced temperatures and reduced rainfall resulting in a cooler but more humid climate as a result of the reduced evaporation. This climate change led to the development of peri-glacial conditions in the Snowy Mountains (Coventry and Walker 1977); the endorheic Lake George east of Canberra reached $37 \mathrm{~m}$ depth of freshwater (Coventry and Walker 1977) and Lake Mungo, $320 \mathrm{~km}$ south east of FGAZRS reached its highest level $(5.5 \mathrm{~m})$ of freshwater (Fitzsimmons et al. 2015). These conditions have not occurred in the past $11 \mathrm{ka}$ since the beginning of the Holocene. The age of the water at Smith's and Dawson's bores of the same age suggests that regionally significant recharge may have occurred at this time.

\section{Summary and conclusion}

At Fowlers Gap in the semi-arid zone of western New South Wales, Australia, the rainfall and runoff in a $460 \mathrm{~km}^{2}$ catchment has been investigated in detail using a range of integrated hydrological and hydrogeological methods that have included installation of a tipping-bucket rainfall monitoring system of 18 gauges, a climate station, runoff monitoring, geological investigation, installation of groundwater monitoring boreholes, surface geophysics, stream bed thermal and pressure analysis, downhole geophysical logging, hydrochemical analysis and interpretation using water chemistry and environmental isotopes. Fortuitously, the monitoring equipment was installed in time to monitor the response of the catchment to the most extreme 36-h rainfall event recorded in the past 50 years during January 2015.

The wealth and breadth of data provides a range of evidence and inferences which are presented in detail in the paper but can be summarised conceptually as follows. Runoff is produced by rainfalls above thresholds of $10-20 \mathrm{~mm}$ due to the relatively low infiltration capacity of low permeability soils. This leads to rapid flows in Fowler's Gap Creek with flood wave increasing from 0.53 to $4.66 \mathrm{~km} / \mathrm{h}$ in a downstream direction. During flow events, infiltrating water quickly fills available pockets of shallow permeable deposits in the streambed and overbank deposits but owing to low permeability clay layers and entrapped air, recharge into the shallow aquifer is highly variable in time and space. Overall, there is clear evidence of differing recharge responses along the creek, and that the cumulative response of multiple, subsequent small-magnitude rainfall-runoff events can contribute much more recharge than one large-magnitude event. The observed recharge responses in 2015-2016 were only approximately half the magnitude of the long-term recharge rate. Hence previous years with multiple, closely space stream flowgenerating rainfalls must have occurred more frequently at certain times in the past. Based on the long-term rainfall records and environmental tracer evidence it is very likely that 1974 in particular, and likely also 2010-2011, were key periods for such substantial recharge. There is also a deeper aquifer which is hydrochemically distinct from the shallow aquifer and shows no hydraulic responses to recharge, consistent with the geophysical information suggesting that a substantial clay layer separates the aquifers. It is unknown whether the deeper aquifer receives recharge via flow paths linking to a possible recharge zone at higher elevations in the catchment, but a long flow path is required to explain why water sampled from the deeper aquifer is of Pleistocene age.

The results illustrate how groundwater recharge is the result of complex interplays between the local expression of the prevailing climate (rainfall intensity and clustering of events), local geology (superficial deposits in particular), and topographic effects on runoff generation. Great care is therefore needed in attributing or predicting generalised changes in recharge to changes in climate in dryland environments without first unravelling the dynamic processes governing groundwater recharge in the locality of interest. The result should prompt more detailed and long-term field investigation in other arid zone locations and reinforce the increasing amount of literature indicating the highly sporadic, and nonlinear nature of recharge in arid environments.

Supplementary Information The online version contains supplementary material available at https://doi.org/10.1007/s10040-020-02284-x.

Acknowledgements The Water Research Laboratory, UNSW Sydney provided the data warehouse facilities.

Funding Open Access funding enabled and organized by Projekt DEAL. The National Collaborative Research Infrastructure Strategy (NCRIS) for Australia was funded by the Federal Government and provided the funding to establish the network of tipping-bucket rain gauges, climate stations and gauging sites. MOC was supported by funding from the 
European Community's Seventh Framework Programme (FP7/20072013) under grant agreement No. 299091 and by an independent research fellowship from the UK Natural Environment Research Council (NE/ P017819/1). This project has received funding from the European Union's Horizon 2020 research and innovation programme under the Marie Skłodowska-Curie grant agreement No. 835852.

Open Access This article is licensed under a Creative Commons Attribution 4.0 International License, which permits use, sharing, adaptation, distribution and reproduction in any medium or format, as long as you give appropriate credit to the original author(s) and the source, provide a link to the Creative Commons licence, and indicate if changes were made. The images or other third party material in this article are included in the article's Creative Commons licence, unless indicated otherwise in a credit line to the material. If material is not included in the article's Creative Commons licence and your intended use is not permitted by statutory regulation or exceeds the permitted use, you will need to obtain permission directly from the copyright holder. To view a copy of this licence, visit http://creativecommons.org/licenses/by/4.0/.

\section{References}

Acworth RI, Rau GC, Cuthbert MO, Jensen E, Leggett K (2016a) Longterm spatio-temporal precipitation variability in arid-zone Australia and implications for groundwater recharge. Hydrogeol J 24:905921. https://doi.org/10.1007/s10040-015-1358-7

Acworth RI, Halloran LJS, Rau GC, Cuthbert MO, Bernardi TL (2016b) An objective method to quantify groundwater compressible storage using earth and atmospheric tides. Geophys Res Lett 43(22):1167111678. https://doi.org/10.1002/2016gl071328

Acworth I (2019) Investigating groundwater. International Contributions to Hydrogeology, vol 29. International Association of Hydrogeologists, Wallingford, UK, CRC, Boca Raton, FL

Allen D, Merrick N (2005) Towed geo-electric arrays for analysis of surface water groundwater interaction. SAGEEP 2005, Environmental and Engineering Geophysical Society, Denver, CO, pp 473-482. https://doi.org/10.4133/1.2923493

Assayag N, Rivé K, Adler M, Jézéquel D, Agrinier P (2006) Improved method for isotopic and quantitative analysis of dissolved inorganic carbon in natural water samples. Rapid Commun Mass Spectrom 20(15):2243-2251. https://doi.org/10.1002/rcm.2585

Beavis FC, Beavis JC (1984) Geology, engineering geology and hydrogeology of Fowler's Gap Station. Research series no. 6, Fowlers Gap Arid Zone Research Station. Univ N South Wales, Cardiff, Australia

Bianchi WC, Haskell EE (1996) Air in the vadose zone as it affects water movements beneath a recharge basin. Wat Res Res 2(2):315-322. https://doi.org/10.1029/WR002i002p00315

Blasch KW, Ferré TPA, Hoffmann JP, Fleming JB (2006) Relative contributions of transient and steady state infiltration during ephemeral streamflow. Water Resour Res 42. https://doi.org/10.1029/ 2005WR004049

Brown CM, Jackson KS, Lockwood KL, Passmore VL (1982) Source rock potential and hydrocarbon prospectivity of the Darling Basin. BMR J Aust Geol Geophys 7(1):23-33

Bureau of Meteorology (2020) Indian Ocean Influences on Australian Climate. http://www.bom.gov.au/climate/iod/. Accessed December 2020

Clark I, Fritz PD (1997) Environmental isotopes in hydrogeology. Lewis, Boca Raton, FL, 328 pp

Cordery I (2004) Arid zone surface runoff: a significant resource in Australia. Aust J Water Eng 8(1):37-42
Cordery I, Pilgrim D, Doran DG (1983) Some hydrological characteristics of arid western New South Wales. Hydrology and water resources symposium, Hobart, Australia, November 1983, The Institution of Engineers, Barton, Australia, pp 8-10

Coventry RJ, Walker PH (1977) Geomophological significance of Late Quaternary deposits of the Lake George area, NSW. Aust Geogr 13(6):369-376. https://doi.org/10.1080/00049187708702715

Cuthbert MO (2014) Straight thinking about groundwater recession. Water Res Res 50(3). https://doi.org/10.1002/2013WR014060

Cuthbert MO, Acworth RI, Andersen MS, Larsen JR, McCallum AM, Rau GC, Tellam JH (2016) Understanding and quantifying focused, indirect groundwater recharge from ephemeral streams using water table fluctuations. Water Resour Res 52:827-840. https://doi.org/10. 1002/2015WR017503

Cuthbert MO, Taylor RG, Favreau G, Todd MC, Shamsudduha M, Villholth KG, MacDonald AM, Scanln BR, Kotchoni DOV, Vouillamoz J-M, Lawson FMA, Adjomayi PA, Kashaigili J, Seddon D, Sorenson JPR, Ebrahim GY, Owor M, Nyenje PM, Nazoumou Y, Goni I, Ousmane BI, Sibanda T, Ascott MJ, MacDonald DMJ, Agyekum W, Koussoube Y, Wanke H, Kim H, Wada Y, Lo M-H, Oki T, Kukuric N (2019a) Observed controls on resilience of groundwater to climate variability in sub-Saharan Africa. Nature 572:230-234 https://www.nature.com/articles/ s41586-019-1441-7. Accessed December 2020

Cuthbert MO, Gleeson T, Moosdorf N, Befus KM, Schneider A, Hartmann J, Lehner B (2019b) Global patterns and dynamics of climate-groundwater interactions. Nat Clim Change 9:137-141. https://doi.org/10.6084/m9.figshare.7393304

Dahan O, Shani Y, Enzel Y, Yechiele Y, Yakirevich A (2007) Direct measurements of floodwater infiltration into shallow alluvial aquifers. J Hydrol 344:157-170. https://doi.org/10.1016/j.jhydrol.2007. 06.033

Dahan O, Tatarsky B, Enzel Y, Kulls C, Seely M, Benito G (2008) Dynamics of flood water infiltration and ground water recharge in hyperarid desert. Ground Water 46:450-461. https://doi.org/10. 1111/j.1745-6584.2007.00414.x

De Dekker P, Munday CI, Brocks J, O'Loingsigh AGE, Hope J, Norman M, Stuut J-BW, Tapper NJ, van der Kaars S (2014) Characterisation of the major dust storm that traversed over eastern Australia in September 2009: a multidisciplinary approach. Aeolian Res 15: 133-149. https://doi.org/10.1016/j.aeolia.2014.07.003

De Vries JJ, Simmers I (2002) Groundwater recharge: an overview of processes and challenges. Hydrogeol J 10:5-17

Dunkerly D (2008) Flow chutes in Fowlers Creek, arid western New South Wales, Australia: evidence for diversity in the influence of trees on ephemeral channel form and process. Geomorphology 102: 232-241. https://doi.org/10.1016/j.geomorph.2008.05.004

Dunkerly DL (2019) Rainfall intensity bursts and the erosion of soils: an analysis highlighting the need for high temporal resolution rainfall data for research under current and future climates. Earth Surf Dynam 7:345-360. https://doi.org/10.5194/esurf-7-345-2019

Faybishenko BA (1995) Hydraulic behaviour of quasi-saturated soils in the presence of entrapped air: laboratory experiments. Water Resour Res 31(10):2421-2435. https://doi.org/10.1029/95WR01654

Fink D, Hotchkis M, Hua Q, Jacobsen G, Smith AM, Zoppi U, Child D, Mifsud C, van der Gaast H, Williams A, Williams M (2004) The ANTARES AMS facility at ANSTO. NIM B 223-224:109-115

Fitzsimmons KE, Stern N, Murray-Walace CV, Truscott W, Pop C (2015) The Mungo mega-Lake event, semi-arid Australia: nonlinear descent into the last ice age-implications for human behaviour. PLoS One 10(6):e0127008. https://doi.org/10.1371/journal. pone. 0127008

Gee GW, Hillel D (1988) Groundwater recharge in arid regions: review and critique of estimation methods. Hydrol Proc 2(3):255-266. https://doi.org/10.1002/hyp.3360020306 
Gleeson T, Cuthbert MO, Ferguson G, Perroneet D (2020) Global groundwater sustainability, resources and systems in the Anthropocene. Annu Rev Earth Planet Sci 48. https://doi.org/10. 1146/annurev-earth-071719-055251

Halloran LJSS, Roshan H, Rau GC, Andersen MS (2016) Calculating water saturation from passive temperature measurements in nearsurface sediments: development of a semi-analytical model. Adv Water Resour 89:67-79. https://doi.org/10.1016/j.advwatres.2016. 01.007

Healy RW (2010) Estimating groundwater recharge. Cambridge Univ Press, Cambridge, UK

Lange J (2005) Dynamics of transmission losses in a large arid stream channel. J Hydrol 306:112-126. https://doi.org/10.1016/j.jhydrol. 2004.09.016

Lerner DN, Issar AS, Simmers I (1990) Groundwater recharge: a guide to understanding and estimating natural recharge. Int. Contrib. Hydrogeol. 8, International Association of Hydrogeologists, Goring, UK

Lloyd JW (1986) A review of aridity and groundwater. Hydrol Proc 1:1. https://doi.org/10.1002/hyp.3360010107

Loke M (2001) RES2DINV Ver 3.4 manual: rapid 2D and 3D resistivity and IP inversion using the least squares method. https://www. geoelectrical.com. Accessed 30 September 2018

Loke M (2016) Tutorial: 2-D and 3-D electrical imaging surveys. https:// wwwgeotomosoftcom. Accessed 26 June 2016

McCallum AM, Andersen MS, Larsen J, Rau GC, Acworth RI (2014) River-aquifer interactions in a semi-arid environment investigated using point and reach measurements. Water Resour Res 50(4): 2815-2829. https://doi.org/10.1002/2012WR012922

McKay G (2007) The life blood of floods: flood producing weather systems. 47th Annual NSW Floodplain Management Conference, 27 February -1 March 2007, Gunnedah NSW, Australia

Neef G, Bottrill RS, Richie A (1995) Phanerozoic stratigraphy and structure of the northern barrier ranges, western New South Wales. Aust J Earth Sci 42(6):557-570

Osborne HB, Renard KG, Simanton JR (1979) Dense networks to measure convective rainfalls in Southwest United States. Water Resour Res 15:1701-1711. https://doi.org/10.1029/WR015i006p01701

Parkhurst DL, Appelo CAJ (2003) PHREEQC for windows: a computer program for speciation, batch-reaction, one-dimensional transport, and inverse geochemical calculations. USGC, Washington, DC
Pilgrim DH, Chapman TG, Doran D (1988) Problems of rainfall-runoff modelling in arid and semiarid regions. Hydrol Sci J 33(4):379-400. https://doi.org/10.1080/02626668809491261

Rasmussen TC, Crawford LA (1997) Identifying and removing barometric pressure effects in confined and unconfined aquifers. Ground Water 35:502-511. https://doi.org/10.1111/j.1745-6584.1997. tb00111.x

Rau GC, Halloran LJS, Cuthbert MO, Andersen MS, Acworth RI, Tellam JT (2017) Characterising the dynamics of surface watergroundwater interactions in intermittent and ephemeral streams using streambed thermal signatures. Adv Water Resour 107:354369. https://doi.org/10.1016/j.advwatres.2017.07.005

Sharon D (1981) The distribution in space of local rainfall in the Namib Desert. J Clim 1:67-75

Simmers I. (1997) Recharge of phreatic aquifer in (semi-) arid areas. Balkema

Shanafield M, Cook P (2014) Transmission losses, infiltration and groundwater recharge through ephemeral and intermittent streambeds: a review of applied methods. J Hydro 511:518-529. https:// doi.org/10.1016/j.jhydrol.2014.01.068

Shanafield M, Gutierrez-Jurado K, White N, Hatch M, Keane R (2020) Catchment-scale characterisation of intermittent stream infiltration: a geophysics approach. J Geophys Res Earth Surf 125(2). https:// doi.org/10.1029/2019JF005330

Tadros CV, Hughes CE, Crawford J, Hollins SE, Chisari R (2014) J Hydrol 513:262-273. https://doi.org/10.1016/j.jhydrol.2014.03.031

Turnadge C, Crosbie RS, Barron O, Rau GC (2019) Comparing methods of barometric efficiency characterization for specific storage estimation. Groundwater 57:844-859. https://doi.org/10.1111/gwat.12923

Villeneuve S, Cook PG, Shanafield M, Wood C, White N (2015) Groundwater recharge via infiltration through an ephemeral riverbed, Central Australia. J Arid Environ 117:47-58. https://doi.org/10. 1016/j.jaridenv.2015.02.009

Wang Z, Feyen J, van Genuchten M T, Nielsen DR (1998) Air entrapment effects on infiltration rate and flow instability. Wat Res Res 34(2):213-222. https://doi.org/10.1029/97WR02804

Publisher's note Springer Nature remains neutral with regard to jurisdictional claims in published maps and institutional affiliations. 